\title{
The Variscan foreland in Poland revisited: new data and new concepts
}

\author{
Marek NARKIEWICZ ${ }^{1, *}$ \\ 1 Polish Geological Institute - National Research Institute, Rakowiecka 4, 00-975 Warszawa, Poland
}

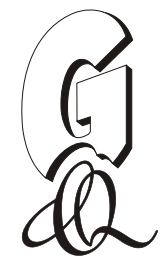

Narkiewicz, M., 2020. The Variscan foreland in Poland revisited: new data and new concepts. Geological Quarterly, 64 (2): 377-401, doi: 10.7306/gq.1511

Associate Editor: Leszek Marks

\begin{abstract}
An earlier concept of the Variscan foreland in Poland (Narkiewicz, 2007) is reconsidered in the light of new stratigraphic, tectonic and geophysical evidence, providing new data on Devonian sedimentation, Carboniferous magmatism and the deep crustal structure of SE Poland. Regional comparisons with the tectonic evolution of Central Europe and the Black Sea region show that the subsidence pattern in the foreland was controlled by alternating phases of accelerated convergence and tectonic standstill along the southern margin of Euramerica. In particular, the Bretonian (Devonian/Carboniferous) compressional deformation resulted from intensified orogenic convergence in the West-Central European Variscides leading to closure of the Saxo-Thuringian Basin and East-Sudetic back-arc basin. Another turning point in the regional tectonosedimentary development around the Mississippian-Pennsylvanian boundary was probably related to the termination of terrane collision in the Black Sea region. Late Pennsylvanian basin inversion was associated with a roughly $\mathrm{N}-\mathrm{S}$ tectonic shortening. This was partly due to displacement along pre-existing basement discontinuities comprising reactivated Caledonian sutures that also pre-determined the Devonian-Carboniferous basin boundaries. Consequently, deeply-rooted tectonic zones, including the Kraków-Lubliniec and Holy Cross faults and the Teisseyre-Tornquist Zone, focussed maximum compressional and transpressional deformation and associated uplift. Such a concept of terminal Variscan tectonism, termed here the "decoupled model", is discussed with reference to the recently proposed "coupled model". The latter assumes a wide extent of the Variscan Orogen, reaching as far as the marginal Radom-Kraśnik Fold-and-Thrust Belt linked with the Bohemian Massif through a major basal detachment. It is concluded that the "decoupled model" is more consistent with the documented seismic and structural evidence as well as with the present knowledge of the heterogeneous pre-Devonian basement in southern Poland.
\end{abstract}

Key words: Variscides, foreland basins, lithospheric memory, far-field stress, basin inversion.

\section{INTRODUCTION}

The Variscan foreland in Poland comprises Devonian and Carboniferous basins that developed in front of the Variscan external belt attributed to the Rhenohercynian Zone (Narkiewicz, 2007). Erosional remnants of the basin-fill form outcrops and subcrops extending between the frontal part of the orogen in the south and west, and elevated areas of the East European Platform in the north-east. They compose a 100-150 km wide belt in the northern Pomerania area, narrowing to $<50 \mathrm{~km}$ in central Poland and again widening to $\sim 400 \mathrm{~km}$ in the SE part of the country (Fig. 1). The Variscan Front is well defined in Silesia where it corresponds to the thick-skinned Orlova and Michałkowice thrusts at the eastern margin of the Moravian-Silesian Fold-and-Thrust Belt (Kotas, 1994). Farther north and west it is concealed beneath thick Permian-Mesozoic

\footnotetext{
*E-mail: marek.narkiewicz@pgi.gov.pl
}

Received: September 16, 2019; accepted: November 25, 2019; first published online: February 18, 2020 strata and its architecture is hypothetical. Based on extrapolation from southern Poland and on regional analogies it is interpreted as a single master thrust similar to that in the Ardennes Massif (Oncken et al., 1999) or to a series of thrusts known from the northern part of the Rhenish Massif (Behr et al., 1984). Its course is here assumed after the earlier study (Narkiewicz, 2007) based partly on Jubitz et al. (1986) and Pożaryski and Karnkowski (1992).

In the earlier paper (Narkiewicz, 2007) the data then available on the Devonian and Carboniferous of the Variscan foreland were summarized and discussed. Its tectono-sedimentary development was interpreted within a broader tectonic and palaeogeographic framework of the post-Caledonian southern passive margin of Euramerica evolving into an active margin and finally transformed into a continental collision zone in the late Devonian and Carboniferous. Since that publication, important new data and interpretations have appeared, which necessitates supplementing and reconsidering the earlier results.

In particular, new synthetic papers have been published on the depositional development of the Łysogóry Basin (Narkiewicz, 2011a), the Lublin Basin (Waksmundzka, 2010; Narkiewicz, 2011b, Narkiewicz et al., 2011a) and on the general geology of SE Poland (Buła et al., 2008). New data on the 


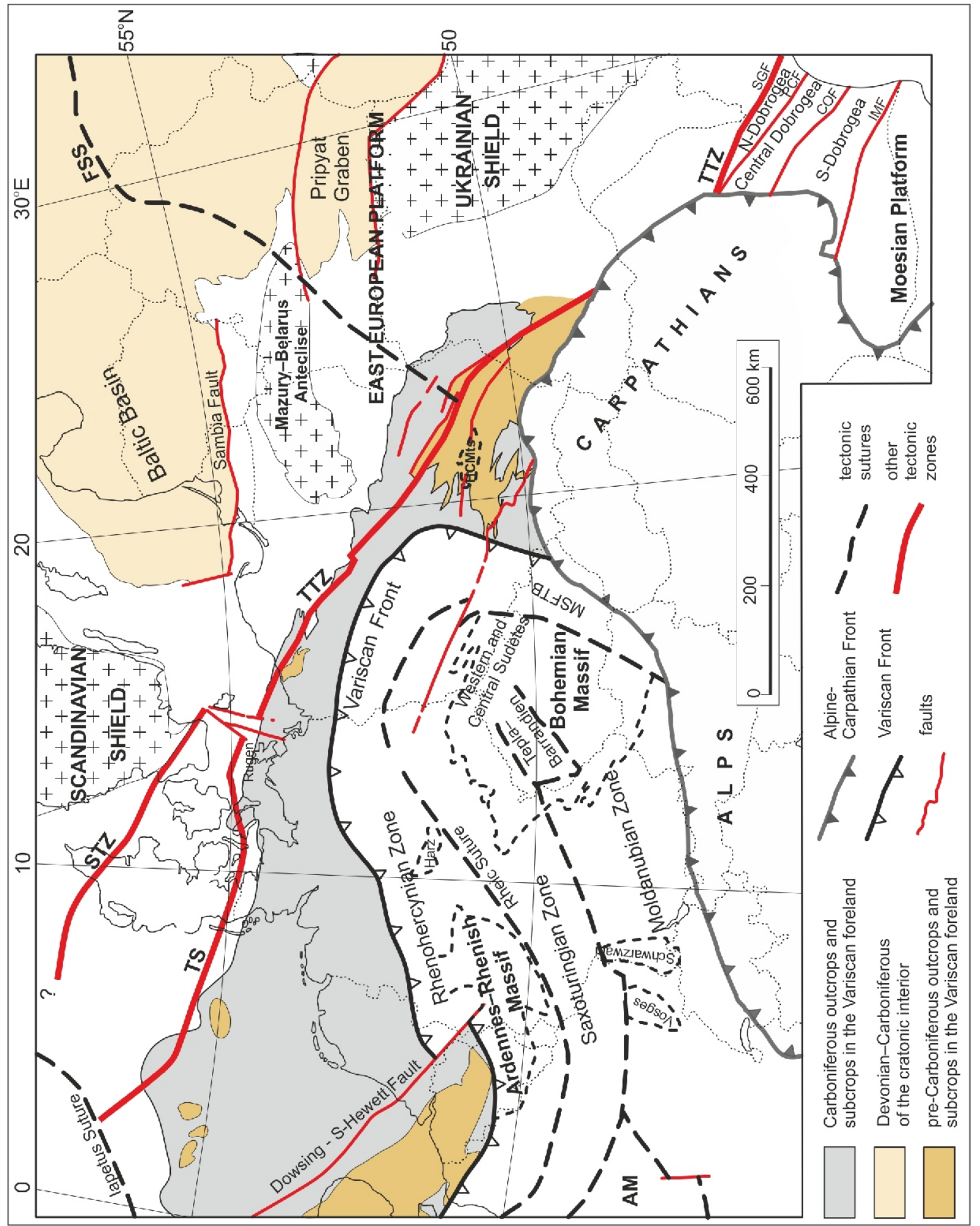

命

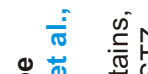

은 억 돈

진

过

췽 중다

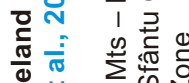

잉

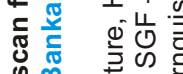

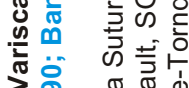

일

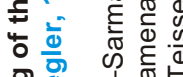

这

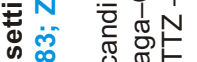

땡․

章

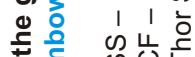

政则

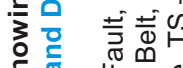

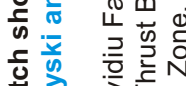

क्षे

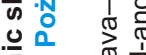

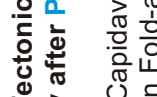

전

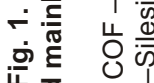

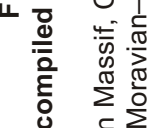

일

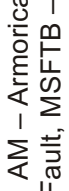


age of igneous processes were obtained for the cratonic basement in NE Poland (summarized in Krzemińska et al., 2017) the Lublin region (Pańczyk and Nawrocki, 2015), the Holy Cross Mts. (Nawrocki et al., 2013; Krzemińska and Krzemiński, 2019) and the Upper Silesian Basin (Jirásek et al., 2013).

Several recent studies, mostly based on new reflection seismic data, are devoted to the deep structure and tectonic development of the Lublin Basin and adjoining regional units (Narkiewicz et al., 2015; Tomaszczyk, 2016; Krzywiec et al., 2017a, b; Tomaszczyk and Jarosiński, 2017; Kufrasa et al., 2017, 2019). These studies deserve particular attention here as they partly propose new or invoke previous controversial tectonic ideas having broader implications for the Variscan Foreland in genera (Krzywiec et al., 2017a; Aleksandrowski and Mazur, 2017). These issues are discussed below within the framework of new regional concepts regarding the basement structure of Poland with particular emphasis on the nature and course of the Teisseyre-Tornquist Zone (TTZ) at the margin of the East European Platform (Mazur et al., 2015; Narkiewicz et al., 2015 Narkiewicz and Petecki, 2016, 2017, 2019).

\section{TECTONIC AND PALAEOGEOGRAPHIC BACKGROUND}

Soon after the amalgamation of Baltica-Avalonia and Laurentia into the Euramerica continent in the Late Silurian, the newly formed Caledonian Orogen of northern Europe underwent gravitational collapse. The disintegration was additionally stimulated by back-arc extension connected with the subduction of the Rheic Ocean lithosphere beneath the Euramerican Plate (Ziegler, 1990; Franke, 2000). This process was probably responsible for the development in the Emsian of a narrow Rhenohercynian Ocean extending from SW England in the west to Moravia in the east. On the other hand, narrowing of the Rheic Ocean led to the continental collision of Gondwana with Euramerica preceded by a northward drift and Devonian to Early Carboniferous amalgamation of smaller Gondwana-derived units of the Armorican Terrane Assemblage (Franke et al., 2017). The convergence of both continents continued during the Early Carboniferous, and since that time the newly established Pangea Supercontinent displayed a consistent drift history. The final phase of the oblique dextral collision occurred in the Late Carboniferous, resulting in the formation of a Himalaya-type Variscan Orogen of Western and Central Europe stretching from the Iberian Massif in the west to the Bohemian Massif in the east. The orogen comprises in its innermost part the Moldanubian Zone (including the Vosges, Schwarzwald and southern part of the Bohemian Massif), the Tepla-Barrandian Zone in the central part of the Bohemian Massif, the Saxothuringian Zone limited by the Rheic Suture to the north, and the external fold-and-thrust belt of the Rhenohercynian Zone with the classic outcrops of the Ardennes-Rhenish Massif and Harz (Fig. 1).

The Variscan Orogen is concealed towards the south-east beneath the Alpine-Carpathian belt. Nevertheless, its farther eastward extent is suggested by provenance analysis of exotic clasts in the Carpathian flysch as well as by dating of isolated basement outcrops in the Inner Carpathians (e.g., Znosko, 1992; Gawęda, 2007). The SE part of the orogenic belt can be reconstructed in the Black Sea region, between the Balkan Mountains and Rhodopes in the west and the Caucasus in the east (Fig. 2). There, the Moesian Platform, Istanbul Zone and Scythian Platform, labelled as the MOIS Block, were interpreted by Okay and Topuz (2017) as parts of the southern Euramerica margin comprising an external belt of the Variscan Orogen and its foreland basins. To the south these regions are juxtaposed by a zone of crystalline rocks unconformably overlain by Upper Carboniferous to Lower Permian molasse deposits. The belt, termed BASSAC, extending from the Balkan Mts. and the Rhodopes, Strandja and Sakarya terranes to the Caucasus, forms the regional equivalent of the Armorican terranes in W-Central Europe. Tectonic processes acting in these belts likely affected the interior of the EEP and can be deduced from the development of a large rift system comprising the Pripyat Graben in the west through the Dnieper-Donets Rift to the Peri-Caspian Depression in the east (PDD system; Stephenson et al., 2006).

In the Devonian, the southern Euramerica margin, including the Polish Variscan foreland basins, was located in the southern hemisphere in the monsoonal climate of the tropical zone, gradually migrating towards the equator during the Carboniferous (Cocks and Torsvik, 2006; De Vleeschouwer et al., 2012; Golonka and Gawęda, 2012). A global greenhouse climate prevailing during most of the Devonian was characterized by small latitudinal gradients and the absence of larger continental ice-sheets. This favoured the development of extensive carbonate platforms and reefs in the Middle Devonian to Frasnian. Sedimentation, particularly in the tectonically stable cratonic areas, was largely controlled by eustatic changes and biotic events, including one of the largest Phanerozoic mass-extinctions related to the Kellwasser event near the Frasnian-Famennian boundary (Belka and Narkiewicz, 2008). The Famennian was a period of gradual transition from greenhouse to icehouse conditions punctuated by several eustatic pulses and associated black-shale horizons, interpreted in terms of glacial-interglacial cycles (Sandberg et al., 2002; Brezinski et al., 2008). The most prominent of these episodes, the Hangenberg Event near the Devonian-Carboniferous boundary, was associated with one of the most severe biotic perturbations in the Phanerozoic (e.g., Kaiser et al., 2016).

Ensuing climatic cooling during the Early Carboniferous led to an immense Late Paleozoic continental glaciation which started by the end of the Mississippian and lasted until the Permian. The associated glacioeustatic fluctuations were responsible for the cyclic deposition of coal-bearing deposits so characteristic of the Variscan foreland of Europe during most of the Pennsylvanian.

\section{PRE-VARISCAN PATTERN OF BASEMENT UNITS}

Previous results have shown that basement structure was one of the main factors determining the boundaries of particular Devonian-Carboniferous foreland basins and controlling their subsidence development (Narkiewicz, 2007). Recently, the pre-Variscan pattern of the basement blocks has been reconsidered by Narkiewicz and Petecki (2017). They defined several units, briefly described below, which differ in geophysical characteristics and in the development of their Ediacaran to Paleozoic sedimentary cover.

The inner part of the Variscan Orogen in Poland has been ascribed to the Sudetic Domain comprising the Sudetes proper, the Fore-Sudetic Block and the basement of the Wolsztyn-Leszno High (Fig. 3). The NE border of the latter unit is associated with a linear zone of magnetic anomalies traceable to the Mid-German Crystalline High in the W and SW and thus to the Rheic Suture at the NW margin of the Saxothuringian Zone (Franke, 2000; Kroner et al., 2008). The eastern boundary of the Sudetic Domain runs along the 


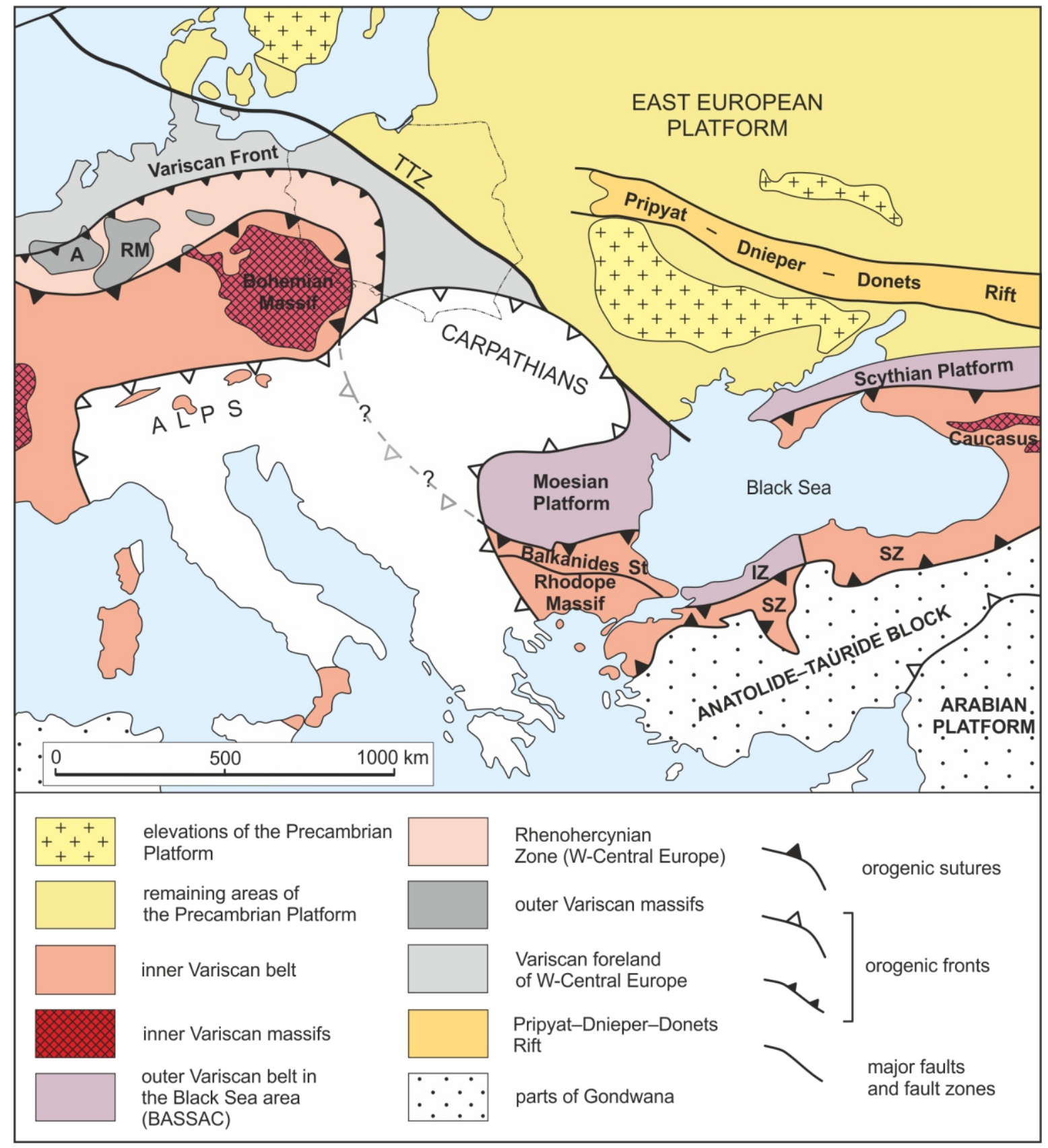

Fig. 2. Variscan Orogen and its foreland in Central Europe and in the Black Sea region (based on Okay and Topuz, 2017: fig. 1, modified)

A - Ardennes, IZ - Istanbul Zone, RM - Rhenish Massif, St - Strandja Massif, SZ - Sakarya Zone, TTZ Teisseyre-Tornquist Zone

Moravian-Silesian Suture between the Central Sudetic terranes and the Brunovistulian basement of the Upper Silesian Block (see below). The suture is a complex thrust zone inclined to the WNW, comprising the Staré Město Belt and its northern continuation in the Fore-Sudetic Block (Jastrzębski, 2012).

The Upper Silesian Block forms the northern part of the triangle-shaped Brunovistulicum unit neighbouring the eastern margin of the Bohemian Massif (Dudek, 1980; Buła and Żaba, 2005). The basement of the block is composed predominantly of Neoproterozoic paragneisses and Paleoproterozoic amphibolites (Buła and Żaba, 2005, 2008) accreted during the Neoproterozoic Cadomian Orogeny (Finger et al., 2000).
Its western part is onlapped by the Moravian-Silesian Fold-and-Thrust Belt forming part of the Variscan external (Rhenohercynian) zone with the frontal thick-skinned Orlova Thrust in the east (Fig. 3). In the eastern part of the block the weakly metamorphosed Ediacaran flysch is overlain by relatively undeformed Paleozoic strata including the thick Devonian to Carboniferous succession of the Upper Silesian Basin (Buła and Żaba, 2005; Buła et al., 2015). The NE boundary of the Upper Silesian Block corresponds to the long-lived Kraków-Lubliniec Fault, interpreted as a pre-Devonian accretionary suture (Buła et al., 1997; Żaba, 1999; Belka et al., 2002). 


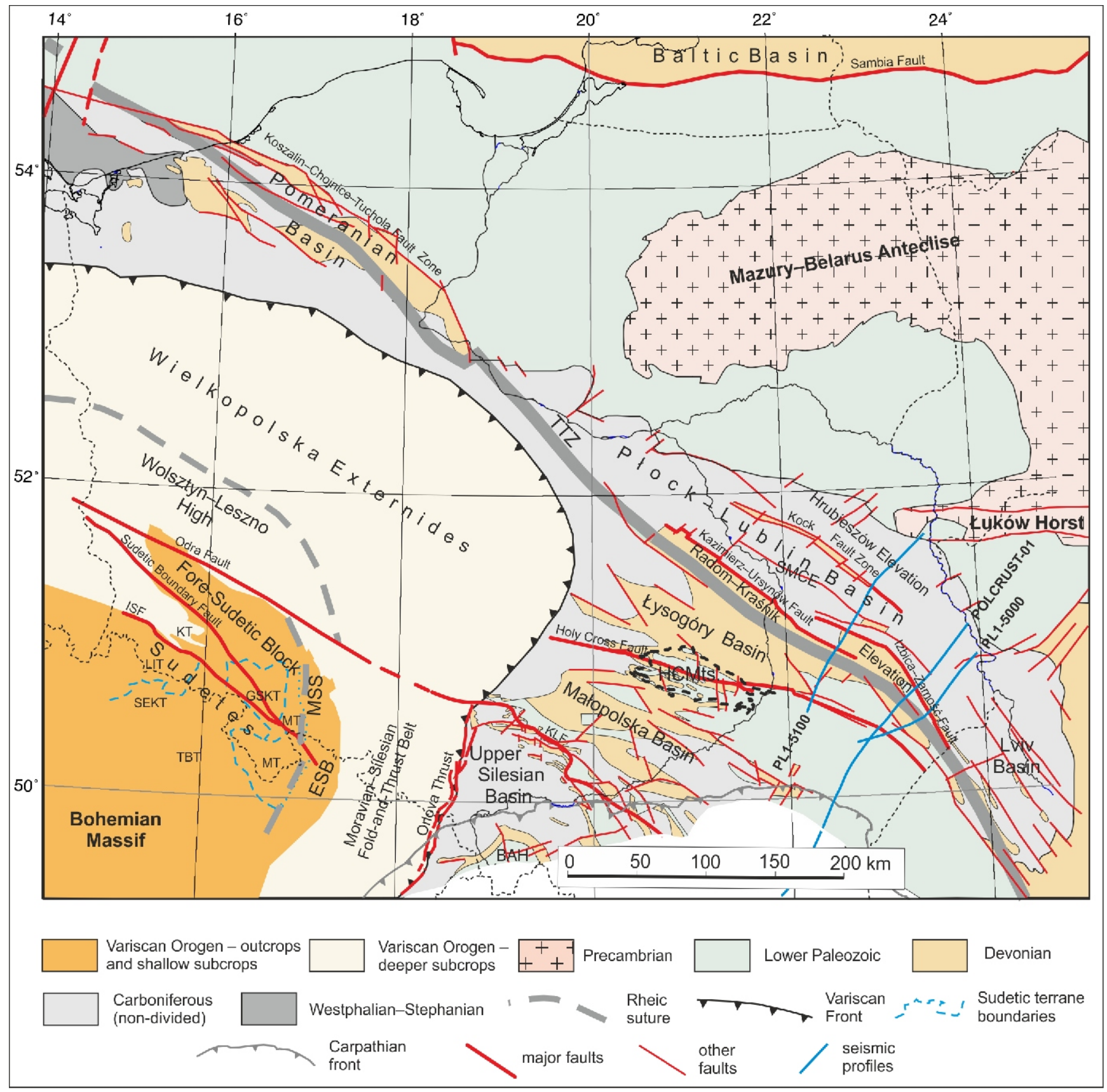

Fig. 3. Regional units of the Variscan foreland within the sub-Permian-Mesozoic map of Poland (based on Pożaryski and Dembowski, 1983)

BAH - Bielsko-Andrychów High; ESB - East Sudetic Belt; HCMts - Holy Cross Mountains; ISF - Intra-Sudetic Fault; KLF Kraków-Lubliniec Fault; SMCE - Stężyca-Mełgiew Central Elevation; MSS - Moravian-Silesian Suture. Tectonostratigraphic terranes in the Sudetes (after Aleksandrowski and Mazur, 2002): GSKT - Góry Sowie-Kłodzko Terrane; KT - Kaczawa Terrane; LIT - Lusatia-Izera Terrane; MT - Moldanubian Terrane; SEKT - South-East Karkonosze Terrane; TBT - Teplá-Barrandian Terrane

The Małopolska Block extends between the Upper Silesian and Łysogóry blocks (Fig. 3). Its deep structure is interpreted as a stack of NE-verging thick-skinned thrusts initially forming a part of the Neoproterozoic (Cadomian) Orogen at the Gondwana margin and later detached as a terrane, analogous to Brunovistulicum (Narkiewicz et al., 2011b, 2015). The pre-Devonian sedimentary cover has been intensely deformed and even, in the case of the Ediacaran flysch, partly metamorphosed (Dadlez et al., 1994; Buła et al., 2008). The final folding was associated with late Caledonian terrane accretion around the Silurian-Devonian boundary (Narkiewicz et al., 2015). The NE boundary corresponds to the Holy Cross Fault whose SE extension can be traced using borehole and geophysical data (Buła et al., 2008; Narkiewicz et al., 2015). 
The Łysogóry Block ${ }^{1}$ occupies a wedge-shaped area between the Holy Cross Fault and the TTZ (Fig. 3). Its basement is unknown but the results of deep seismic investigations point to the crust being of East European Craton (EEC) type (Narkiewicz et al., 2011b, 2015). At the same time, however, the presence of a distinct Lower Paleozoic succession considerably differing from that of the EEC cover supports the concept of a proximal allochthonous terrane translated along the TTZ. The NW extension of the Łysogóry Block beneath the Wielkopolska Externides belt composes a hypothetical Mid-Polish Domain displaying an attenuated EEC-type crust. The Devonian strata and basal Carboniferous rocks are there inaccessible, however, because of the thick Permian-Mesozoic cover.

The Pomeranian Block extends between the TTZ in the NE and the hypothetical crustal discontinuity (Pomeranian Suture) running north-east of the Variscan Front in the south (Narkiewicz and Petecki, 2017). Its basement is unknown but deep seismic refraction data show its affinity to the EEC crust. The Devonian and Carboniferous strata (Matyja, 2006) form wedge-shaped sub-Permian-Mesozoic subcrops unconformably overlying folded Lower Paleozoic rocks extending northeastwards beyond the TTZ as far as the Koszalin-Chojnice-Tuchola Fault Zone (Fig. 3).

The East European Platform (EEP) has a cratonic basement formed mostly of Paleoproterozoic Fennoscandian crust. It is composed of SW-NE trending belts accreted parallel to the suture between Fennoscandia and Sarmatia (Fig. 1; Krzemińska et al., 2017). The SW margin of the EEP formed as a result of Ediacaran rifting in the final stages of breakup of the supercontinent Rodinia, which led to the birth of the Baltica continent corresponding roughly to the present EEP. The sub-Permian-Cenozoic elevations of the EEP basement include the Scandinavian Shield, the Mazury-Belarus Anteclise and the Ukrainian Shield, separated by depressions with a relatively undeformed Ediacaran-Lower Paleozoic cover (Fig. 3). The Devonian-Carboniferous succession rests upon Upper Silurian strata either conformably or with a slight intra-Lochkovian unconformity. An exception is the narrow zone located between the TTZ and the Koszalin-Chojnice-Tuchola Fault Zone mentioned above (Fig. 3). The northern part of the Polish Baltic offshore area comprises Devonian deposits of the marginal part of the Baltic Basin extending farther north-eastwards towards Lithuania, Latvija and Estonia (Belka and Narkiewicz, 2008). Its development was mostly controlled by eustatic fluctuations in the stable EEC interior, and was barely affected by Variscan foreland tectonism.

It is here assumed that the continuous Baltica crust is bounded to the SW by the Teisseyre-Tornquist Zone (TTZ) a tectonic lineament marked by a first-order magnetic gradient and a contrast in crustal structure visible in seismic refraction and magnetotelluric data, and also documented by a few of the deepest reflection seismic lines in SE Poland (Narkiewicz et al., 2015; Narkiewicz and Petecki, 2019). The TTZ is interpreted as the transcurrent zone along which the Pomeranian and Łysogóry proximal terranes were detached from the Tornquist margin of Baltica, translated dextrally and re-accreted during the Late Silurian-earliest Devonian (Dadlez et al., 2005; Narkiewicz et al., 2015). An alternative concept infers continuity of the Paleoproterozoic crust across the TTZ which is interpreted as a Meso-Neoproterozoic intraplate suture (Mazur et al., 2015). According to the present author, this hypothesis, based mainly, if not exclusively, on the results of gravity modeling, lacks support in direct geological and geophysical evidence (see discussion by Narkiewicz and Petecki, 2016, 2019; Narkiewicz, 2019).

\section{STAGES OF DEVELOPMENT OF THE FORELAND BASINS}

The pattern described above of the basement units is to a large extent mirrored in the development of distinct Devonian-Carboniferous basins with contrasting depositional architectures and subsidence histories. The basin boundaries in many cases coincide with the tectonic zones which delimit the underlying crustal blocks. They were reactivated in extensional and compressional regimes, partly with a strike-slip component, both during the subsidence phase and during the later inversion. The lateral translations were, however, very small in scale by comparison with the transcurrent Caledonian tectonics and therefore the presently observed foreland configuration mimics the original palaeogeographic pattern, only with some modification imposed by the late Variscan tectonism (Narkiewicz, 2007; Narkiewicz et al., 2011a; cf. also Szaniawski, 2008 with reference to the Małopolska Block).

In spite of regional, basement-controlled differences there had been a common pattern during the Devonian-Carboniferous development of particular basins seen both in their depositional successions (Fig. 4) and in the subsidence histories (Fig. 5). Thus, several successive stages can be distinguished in the entire Devonian-Carboniferous basin development pointing to external regional controls on their evolution. These stages will be briefly summarized below with particular emphasis on new data and interpretations that have appeared since the original developmental model was published by the author (Narkiewicz, 2007). For more stratigraphic and tectonic details the reader is referred to the earlier paper and to the summaries by Belka and Narkiewicz (2008), McCann et al. (2008) and Belka et al. (2010).

\section{DEVONIAN BASINS}

Over most of the Variscan foreland area various Proterozoic and Paleozoic rocks are unconformably overlain by continental and marginal marine Pragian or Emsian clastic rocks up to $\sim 200 \mathrm{~m}$ thick (Fig. 4). Only in the Lublin Sub-basin and in the Łysogóry Basin did the open marine Late Silurian shallowing-upwards deposition of shaly-carbonate strata continue up to the Lochkovian, culminating in Mid-Lochkovian shallow-water open- to marginal marine clastic deposition (Fig. 6). These strata are onlapped, probably with a small unconformity, by continental alluvial red beds, ascribed mostly to the Emsian and with caliche levels, pointing to a generally warm dry climate (Miłaczewski, 1981; Narkiewicz, 2011b). Stratal thickness is variable, from 200 to $1500 \mathrm{~m}$, with large lateral contrasts due to vertical block movements creating a horst and graben topography (Narkiewicz et al., 2011a).

Around the Early/Middle Devonian boundary, shallow-marine carbonate sedimentation developed and prevailed across the entire depositional realm, except for narrow nearshore clastic belts in the Lublin and Pomerania area. Only the Łysogóry Basin was characterized by an exceptionally high pro-

\footnotetext{
${ }^{1}$ In the previous paper (Narkiewicz, 2007) the unit was named as the Łysogóry-Radom Block; here the abbreviated version is used following Narkiewicz et al. (2011b) and Narkiewicz and Petecki (2017).
} 


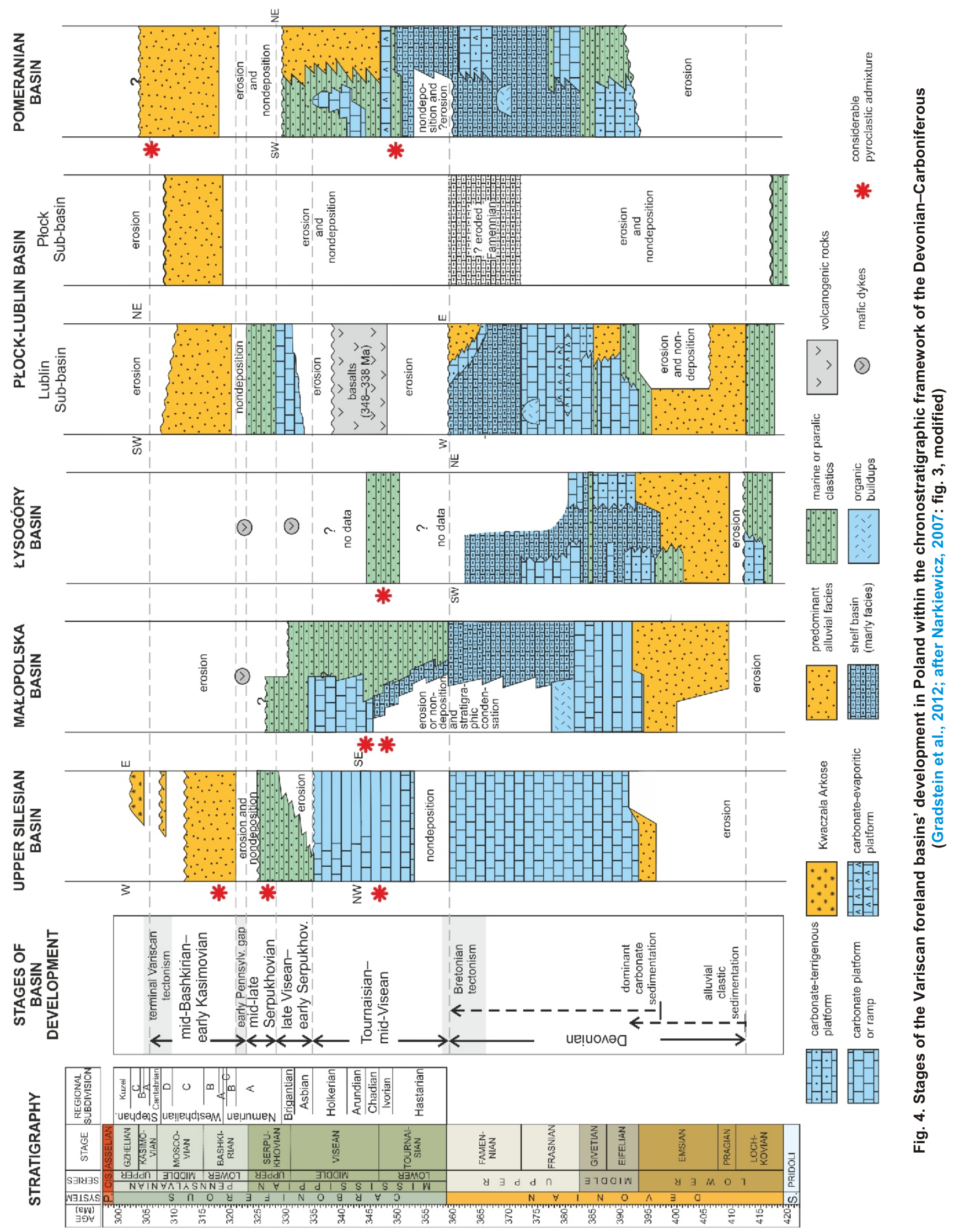




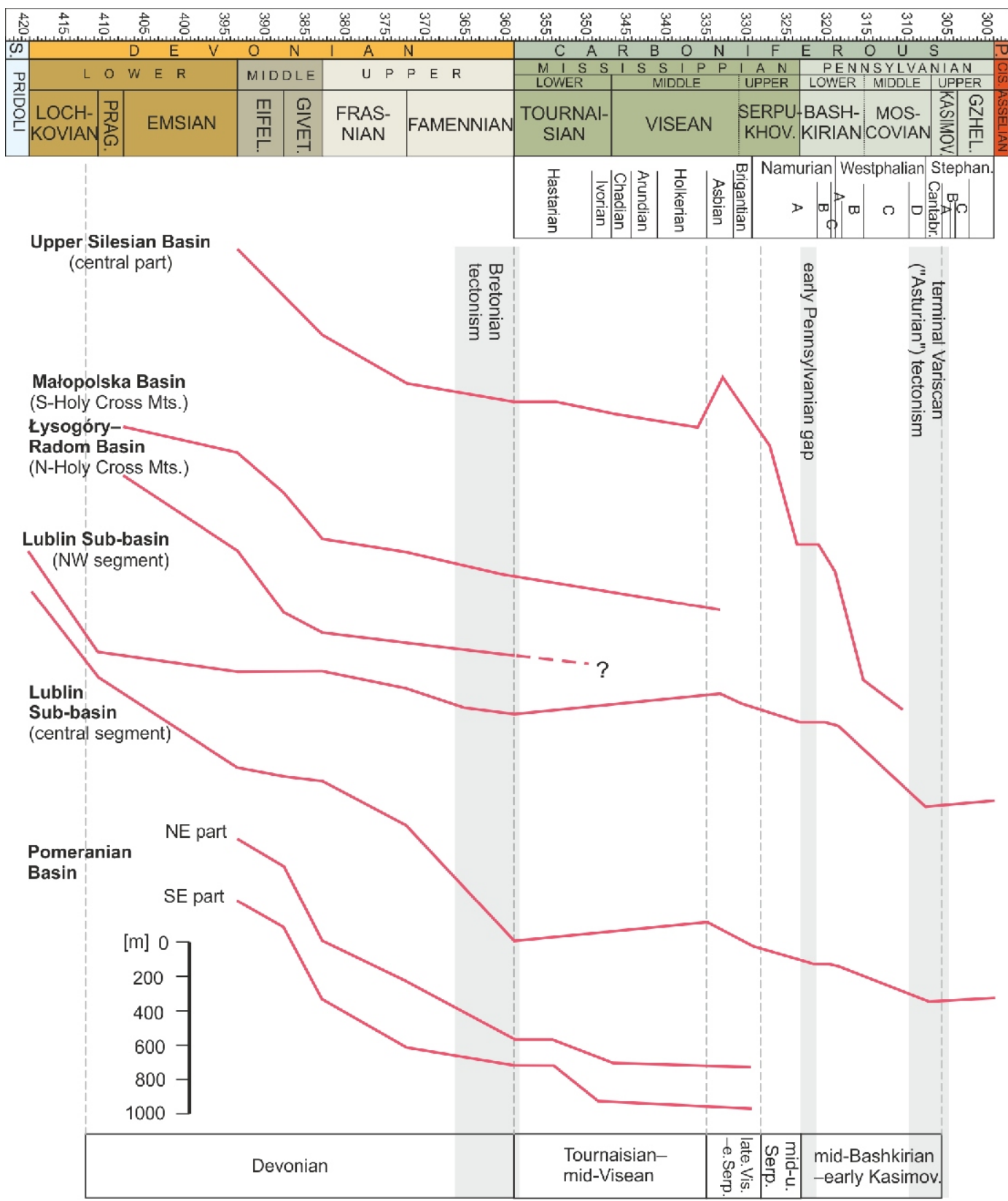

Fig. 5. Stages of the Variscan foreland development in Poland compared with the tectonic subsidence evolution displayed as synthetic curves representative of particular basins (based mainly on McCann et al., 1997; Narkiewicz et al., 1998; Narkiewicz, 2005)

portion of marly and silty deeper-shelf facies. These deposits, exceeding $1 \mathrm{~km}$ in total thickness, replaced carbonate facies under conditions of accelerated subsidence in the elongated depocentre framed by the Holy Cross Fault and the TTZ.

The Late Devonian was characterized by the development of nearshore, attached carbonate platforms and ramps, as well as isolated organic buildups and large reef complexes such as the Dyminy Reef in the western Holy Cross Mts. (Narkiewicz, 1988). Deeper parts of the shelf were dominated by dark-coloured marly carbonates with a pelagic fauna. Their thickness is generally under one kilometer, although in the Lublin Sub-basin it may reach $2.5 \mathrm{~km}$ of mostly Famennian deposits in the depocentre located between the syndepositionally active Kazimierz-Ursynów Fault and the Kock Fault Zone (Narkiewicz et al., 2011a).
Stratigraphic analyses have shown a considerable influence of eustatic fluctuations on the Middle to Upper Devonian depositional architecture (Racki and Narkiewicz, 2000; Belka and Narkiewicz, 2008; Narkiewicz et al., 2011a). Global transgressive events such as the late Emsian sea level rise, the Taghanic Event in the mid-Givetian and the Frasnian transgressions were superimposed on a decreasing tectonic subsidence rate typical of the thermal contraction of the lithosphere following a major (in this case, Emsian) rifting event.

On the other hand, a Devonian extensional or transtensional regime is indicated by depositional records of synsedimentary block tectonics and structural palaeostress data along the Kraków-Lubliniec Fault zone (Żaba, 1999) and in the Holy Cross Mts. (summarized by Racki and Narkiewicz, 2000; Lamarche et al., 2003). The Holy Cross Fault acted as a 


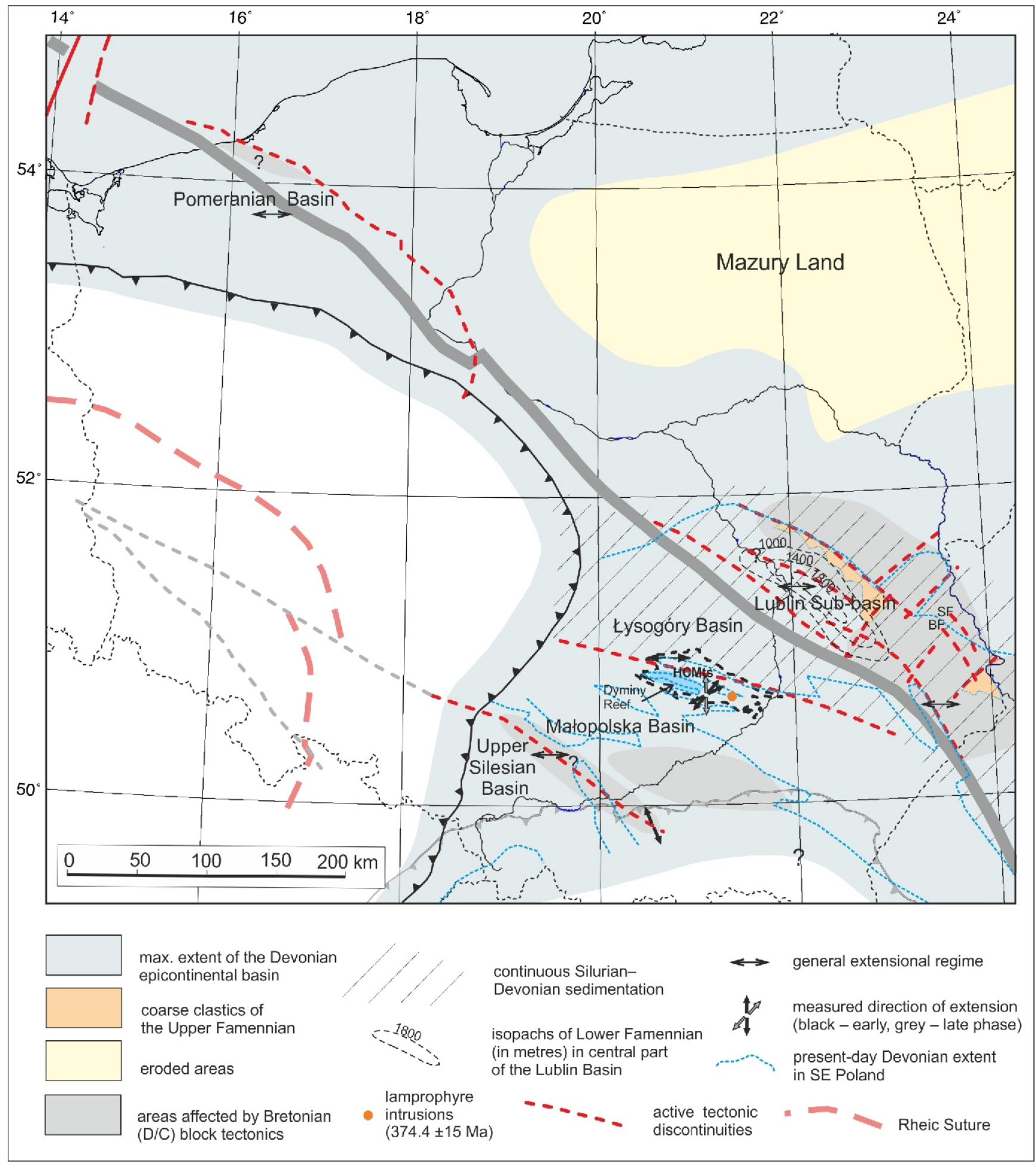

Fig. 6. Devonian palaeogeography of the Variscan foreland in Poland (modified fig. 6 in Narkiewicz, 2007, based on various sources cited in the text)

BF - Białopole Fault, SF - Serebryszcze Fault

major synsedimentary discontinuity separating the more stable Małopolska Basin from the faster subsiding Łysogóry Basin (Narkiewicz, 2011a; Narkiewicz et al., 2015). Also, emplacement of some minor, poorly dated lamprophyre dykes (Migaszewski, 2002) may have resulted from the regional Devonian to Early Carboniferous extension.

Tectonic subsidence in the central part of the Lublin Sub-basin accelerated already in the mid-Frasnian leading to an in- creased sedimentation rate of restricted carbonate-sulphate deposits (Narkiewicz and Narkiewicz, 2008). This local depocentre became even more pronounced in the early Famennian with the onset of rapid accumulation of dark-coloured shaly-carbonate sediments of a deeper shelf (Fig. 6). Associated common synsedimentary boudinage and submarine slumps were probably seismically induced by ongoing tectonic activity of the Kazimierz-Ursynów and Kock Fault zones (Narkiewicz, 2011b). 
In the Pomeranian Basin an extensional regime also prevailed, with alternating pulses of dextral and sinistral transtension and transpression (Żaba and Poprawa, 2006).

\section{LATEST DEVONIAN AND EARLIEST TOURNAISIAN} (BRETONIAN) TECTONISM

Continuous sedimentation across the Devonian-Carboniferous boundary has been documented so far only locally in the Holy Cross Mts. (Malec, 2014) and in the Pomeranian Basin (Matyja et al., 2015). Stratigraphic condensation and gaps spanning the uppermost Devonian and lower part of the Tournaisian have been noted in the Kielce area of the Holy Cross Mts. (Szulczewski, 1995) and in the Upper Silesian and Pomeranian basins (Bełka, 1985; Matyja and Stempień-Sałek, 1994). A sedimentary discontinuity at the base of the Mississippian, commonly labelled the Bretonian unconformity, has been postulated also in the southern part of the Małopolska Basin, e.g., by Jawor and Baran (2004) and Moryc (2006). And, vertical block-movements near the $\mathrm{D}-\mathrm{C}$ boundary in the Kraków-Lubliniec Fault zone have been discussed by Żaba (1999).

The most pronounced late Famennian synsedimentary tectonics have been long known, however, from the Lublin Sub-basin (Narkiewicz, 2007). Vertical block movements and associated erosion locally led to removal of up to $1500 \mathrm{~m}$ of Devonian and Lower Paleozoic strata and to a distinct Bretonian unconformity at the base of the Upper Visean. Recently, seismic sections documented a pattern of thick-skinned vertical and steep reverse faults, with a dextral strike-slip component. The discontinuities strike NW-SE to SW-NE across the Hrubieszów Elevation flanking the depocentre of the Lublin Sub-basin from the NE (Krzywiec et al., 2017a). The faults partly show a positive flower-structure indicating a transpressional regime (Krzywiec, 2007, fig. 4); the same applies to the SE termination of the Kock Fault Zone (Tomaszczyk and Jarosiński, 2017). This major discontinuity probably originated during Ediacaran rifting, was reactivated as a normal fault in the Silurian, and as a steep reverse fault in the Late Devonian-earliest Carboniferous (Tomaszczyk and Jarosiński, 2017). The resulting uplift and erosion of the Hrubieszów Elevation led to south-westwards progradation of marginal marine clastics, carbonates and evaporites grading into continental red beds (Fig. 4; Narkiewicz, 2011b).

POLCRUST-01 seismic reflection data revealed that over most of the SE segment of the Lublin Basin (except for its SW part) Bretonian deformation was more pronounced than the late Carboniferous inversion (see below). Along the NE flank of the basin the Serebryszcze ${ }^{2}$ and Białopole faults (Fig. 6) downthrow the basement top to the SW by $\sim 700$ and $400 \mathrm{~m}$, respectively (Narkiewicz et al., 2015). These approximately vertical discontinuities are associated with some secondary faults composing flower-like structures suggestive of strike-slip deformation. The nearly horizontal Carboniferous base erosionally truncates both faults and the encasing Frasnian to Silurian strata, with only a small indication of reactivation of the Serebryszcze Fault in the Late Carboniferous. Such a pattern testifies to strong vertical block movements predating the late Carboniferous deformation. A similarity between both faults and the SE termination of the Kock Fault Zone suggests that these structures formed a part of the same transpressional zone during the Bretonian tectonism.

\section{TOURNAISIAN TO MIDDLE VISEAN SHELF SEDIMENTATION AND MAGMATISM}

Following the Bretonian block tectonics, the shelf sea retreated entirely from the Lublin and Płock sub-basins, and partly from the Pomeranian Basin (Fig. 7). The remaining inundated area of the Tournaisian to mid-Visean shelf was dominated by terrigenous deposits up to $1 \mathrm{~km}$ thick, commonly with a considerable volcanoclastic admixture. Some fault-controlled elevations became sites of intrashelf and nearshore carbonate platforms. In the Pomeranian Basin alluvial to marginal marine clastic deposits grade into distal offshore fine-grained terrigenous facies. In the Małopolska Basin and in the northern USB a common lithofacies comprised dark-coloured siliceous shales and siltstones.

Carboniferous strata are known from a few borehole sections in the Łysogóry Basin. They comprise a several hundred metres-thick succession of arkosic sandstones intercalated with siltstones and dark shales with palynomorphs of late Tournaisian to ?early Visean age. Abundant admixture of trachytic and rhyolitic volcanoclastic deposits points to volcanic centres developing under continental crust extension. Sedimentological analyses document gravity flows on a submarine slope fed by a narrow shallow shelf to the NE (Jaworowski, 2002). This nearshore clastic belt probably extended along the TTZ thus rimming the eroded area of the former Devonian Lublin Sub-basin. In Pomerania the basin margin paralleled the Koszalin-Chojnice-Tuchola Fault Zone in proximity to a region of late Tournaisian acidic volcanism.

During the Tournaisian to mid-Visean the tectonic subsidence generally decelerated, locally approaching zero (Fig. 5). The regional extension which returned after the Bretonian tectonism favoured magmatic processes which became particularly active near the TTZ around the Tournaisian/Visean boundary. Furthermore, there are some indications of minor mafic magmatism in the HC Mts. in the form of small lamprophyre dykes emplaced probably in the late Tournaisian (Migaszewski, 2002).

The magmatic activity was particularly pronounced in the EEP area including the Lublin region where alkaline basalts up to $230 \mathrm{~m}$ thick developed between late Tournaisian and midVisean times (Pańczyk and Nawrocki, 2015). Alkaline diabase and syenite intruded near the Płock region, while several alkaline plutons are known from NE Poland, including the gabbro-syenite Pisz, syenite Ełk, and syenite-monzogranite Grajewo intrusions (Fig. 7). The age of the intrusive processes has been estimated at 354-338 Ma based on U-Pb isotopes in zircons (summarized by Krzemińska et al., 2017). The maximum activity can be thus correlated with the peak of the pyroclastic input in the upper Tournaisian (Ivorian) of various basins (Fig. 4). It is estimated that the parent magma was derived from an enriched mantle source that was activated by lithospheric extension which apparently affected large parts of the southern Euramerica margin.

LATE VISEAN-EARLY SERPUKHOVIAN PEAK OF THE CARBONIFEROUS TRANSGRESSION

A marine clastic shelf persisted until the late Visean and early Serpukhovian in the Pomeranian and Małopolska basins, and probably also in the Łysogóry Basin (Fig. 8). From the latter area the depositional record is missing, however, and only mi-

\footnotetext{
${ }^{2}$ The structure was named the Dubienka Fault by Narkiewicz et al. (2015) but most probably it corresponds to the Serebryszcze Fault earlier distinguished by Żelichowski (1983 in: Żelichowski and Kozłowski, eds., 1983).
} 


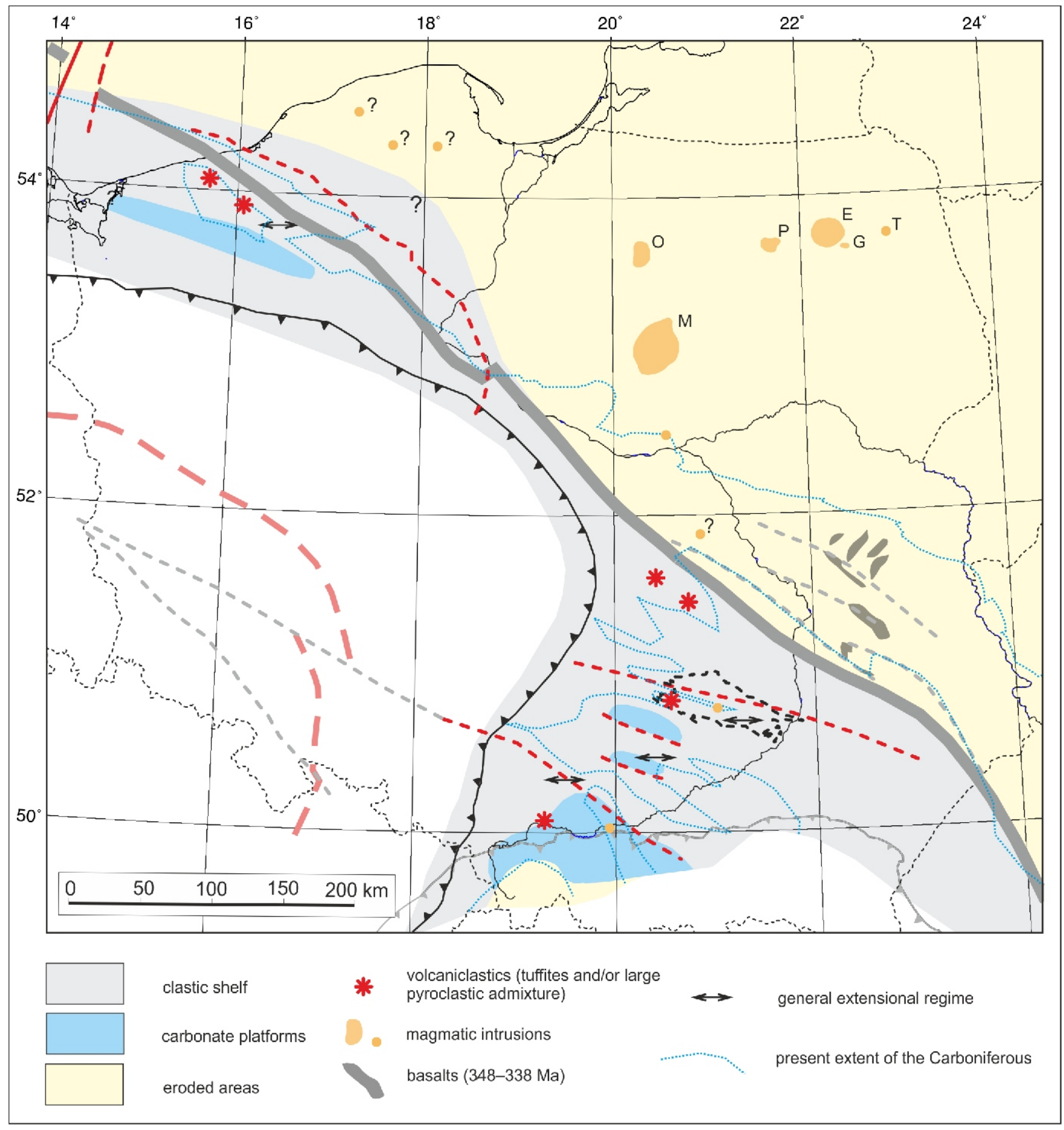

Fig. 7. Tournaisian to mid-Visean palaeogeography of the Variscan foreland in Poland (modified fig. 8 in Narkiewicz, 2007, based on various sources cited in the text)

Magmatic intrusions in the East European Craton area (after Krzemińska et al., 2017):

E - Ełk; G - Grajewo, M - Mława, O - Olsztynek, P - Pisz, T - Tajno; other explanations as in Figure 6

nor mafic magmatism has been noted in a form of diabase dykes hosted by Devonian carbonates in the $\mathrm{HC}$ Mts (Nawrocki et al., 2013). In the south, the westernmost part of the Upper Silesian carbonate platform started to subside rapidly around the Holkerian/Asbian boundary while its remaining portion underwent uplift, disintegration into separate blocks and erosion. In the Bielsko-Andrychów High area the erosion removed locally at least $500 \mathrm{~m}$ of Upper Devonian and Mississippian carbonates (Narkiewicz, 2005). The erosional uncon- formity was onlapped eastwards by upper Visean and lower Serpukhovian clastic deposits composed of marine shales, siltstones and sandstones up to $1500 \mathrm{~m}$ thick. They thin to the east, with a transition to nearshore and continental facies including a few coal beds. This whole succession grades westwards into a thick Moravian-Silesian flysch facies sourced by a prograding Variscan accretionary wedge.

The depositional architecture of the USB resulted from the initiation of a flexural foredeep developed on the descending 
plate of Brunovistulicum under the load of a prograding East-Sudetic orogenic prism, this interpretation being supported by a "knee-shaped" pattern of the tectonic subsidence curve (Fig. 5). Such concept is consistent also with a rapid eastwards migration of the basin depocentre in the late Visean (Bełka, 1987), and with the predominant western source for the clastic material (Gradziński et al., 2005; Fig. 8).

In the Lublin Sub-basin, the Bretonian unconformity was onlapped during the Asbian to early Brigantian by transgressive, shallow-marine shaly-carbonate deposits 50-200 m thick. The southwestern extent of this shelf or ramp is unclear but, by analogy with the previous developmental stage, the basin probably sloped gently across the TTZ belt into slightly deeper shelf environments of the Łysogóry Basin. These were presumably characterized by deposition of hypoxic dark shales, siltstones and quartz arenites with fine-grained greywacke intercalations, typical of the upper Visean of the northern Małopolska Basin described e.g., by Żakowa and Migaszewski (1995) and J. Malec (2010, PGI Kielce, personal comm.). The source area for these sediments could have been at least partly linked with the orogenic prism to the west (unpubl. data of L. Krzemiński, 2010, PGI Warszawa, personal comm.).

In the Pomeranian Basin a distinct regression in the TTZ belt was accompanied by clastic facies progradation southwestwards, thus suggesting tectonic activity in this zone. Earlier developing carbonate platforms were terminated near the Holkerian-Asbian boundary, as in the remaining basins (Fig. 4).

MID-LATE SERPUKHOVIAN EROSION AND PARALIC SEDIMENTATION

During that stage, corresponding approximately to the regional Namurian A subdivision (without the uppermost part), a major change in palaeogeographic pattern occurred in the entire Variscan foreland in Poland. Areas of the Małopolska, Łysogóry and Pomeranian basins were uplifted and eroded whereas the USB and Lublin Sub-basin continued to subside and accumulate coal-bearing paralic successions (Fig. 9).

In the USB the upper Visean marine clastic deposits grade upwards into paralic deposits forming the basal part of an up to $8.5 \mathrm{~km}$ thick coal-bearing succession of the uppermost Mississippian and Pennsylvanian. The paralic succession attained maximum thickness of $3800 \mathrm{~m}$, pinching out eastwards. It is composed mainly of cyclically bedded, fine-grained strata deposited in alluvial plain and in nearshore environments (Kędzior et al., 2007). Several tens of volcanoclastic horizons are represented either by thin tuffite beds (tonsteins) or thicker (up to $15 \mathrm{~m}$ ) mixed terrigenous-pyroclastic whetstones with redeposited volcanogenic material (Jirásek et al., 2013). The centres of this mostly acidic volcanism were probably located in the west in a volcanic arc associated with the westwards subduction of the Brunovistulian Plate beneath the Central Sudetic terranes.

The accumulation of the paralic deposits occurred during a period of increased tectonic subsidence in the foredeep basin, which started in the late Visean. The temporal pattern of accelerating subsidence (Fig. 5) indicates a progressive flexural bending of the Brunovistulicum Plate under the load of an orogenic prism advancing from the west. The depositional regime was a net result of the tectonic subsidence rate and the rates of sediment supply from the eroded orogen and from the Bielsko-Andrychów High.

In the Lublin Sub-basin the open marine shaly-carbonate sedimentation was replaced in the early Serpukhovian by paralic cyclothems composed mostly of terrigenous shallow-marine, deltaic and alluvial deposits. Subordinate components are marine limestone intercalations and thin coal beds. The entire succession ranges up to $\sim 600 \mathrm{~m}$ near the SW basin margin particularly in its central and SE segment, while its thickness is reduced in the Kock Fault Zone and it completely wedges out just east of it. The SW basin margin was presumably located beyond the present tectonic boundary of the Lublin Sub-basin (= Kazimierz-Ursynów Fault), which cross-cuts both facies and sediment-thickness patterns. Nevertheless, upper Mississippian to Pennsylvanian strata are unknown from the Łysogóry and Małopolska regions which probably were undergoing erosion since early Serpukhovian times. Therefore, it seems plausible that the SW margin of the Lublin Sub-basin was controlled by the tectonic activity of the TTZ.

The location of the marine realm responsible for sea incursions in the Lublin Sub-basin is poorly constrained. The Serpukhovian deposits pinch out to the north and west, while they thicken towards the SE in the Lwów Basin. It seems thus probable that the Lublin Sub-basin had a marine connection with basins along the SE part of the Euramerican active margin.

\section{BASHKIRIAN TO MOSCOVIAN - ACTIVE TECTONISM} AND CONTINENTAL SEDIMENTATION

The early Bashkirian (= late Namurian $A$ ) was a time of non-deposition and local erosion over the entire Variscan foreland area (Fig. 4). Recent radiometric ages have confirmed the occurrence of minor mafic magmatism (lamprophyres and diabases) in the Małopolska and Łysogóry parts of the HC Mts. (Nawrocki et al., 2013; Krzemińska and Krzemiński, 2019).

In the USB the renewed sedimentation was characterized by a change in depositional environment - from paralic to mainly alluvial (Fig. 10). During the mid-Bashkirian (= Namurian B) to the mid-Moscovian (= Westphalian $C$ ) the main part of a coal-bearing succession up to $4 \mathrm{~km}$ thick was deposited. Stratal thickness is considerably reduced towards the eastern basin margin due to depositional pinching out of particular units and the development of intraformational erosion levels. Following the widespread non-deposition and erosion in the late Moscovian the renewed coarse-grained clastic sedimentation of the latest Moscovian (= Westphalian D) was limited to the eastern basin margin (Fig. 4). Finally, after another break in sedimentation, arkosic sandstones and conglomerates with variegated mudstones developed locally, reaching a maximum thickness of $400 \mathrm{~m}$. These post-orogenic continental red beds can be correlated with similar strata from the Pilsen-Trutnov Basin Complex in the Czech Republic dated as latest Kasimovian-early Gzhelian (Stephanian B-C; Opluštil et al., 2016).

Parallel with the renewed subsidence, the NE margin of the USB was affected by dextral transpressional deformation - steep east-verging thrusts with accompanying secondary folds and reverse faults striking along the Kraków-Lubliniec Fault zone (Żaba, 1999). A chain of calc-alkaline granitoid intrusions north-east of the fault was previously ascribed to a phase of subhorizontal extension and block uplift in the late Namurian and Westphalian (Żaba, 1999). The recent radiometric data, however, indicate a later age, at approximately the Gzhelian-Asselian boundary interval (Żelaźniewicz et al., 2008; Mikulski et al., 2019) which suggests post-orogenic emplacement.

In the Lublin Sub-basin the reactivation of the depocentre in the mid-Bashkirian (= Namurian B) was associated with its displacement to the NW. The upper Bashkirian to Moscovian succession (Fig. 4), comprising several coal-bearing cyclothems, displays a thickness change from $1500 \mathrm{~m}$ in the axial part of the $\mathrm{NW}$ sector to $\sim 600 \mathrm{~m}$ in the SE. The depocentre migration continued also later, leading to encroachment of sedimentation into the Płock Sub-basin where Westphalian A to C (D?) clastic deposits unconformably overlie the Silurian, attaining a thickness of $1 \mathrm{~km}$ and wedging out to NE. In the Pomeranian Basin the continental clastic deposits of the upper Moscovian to Kasimovian 


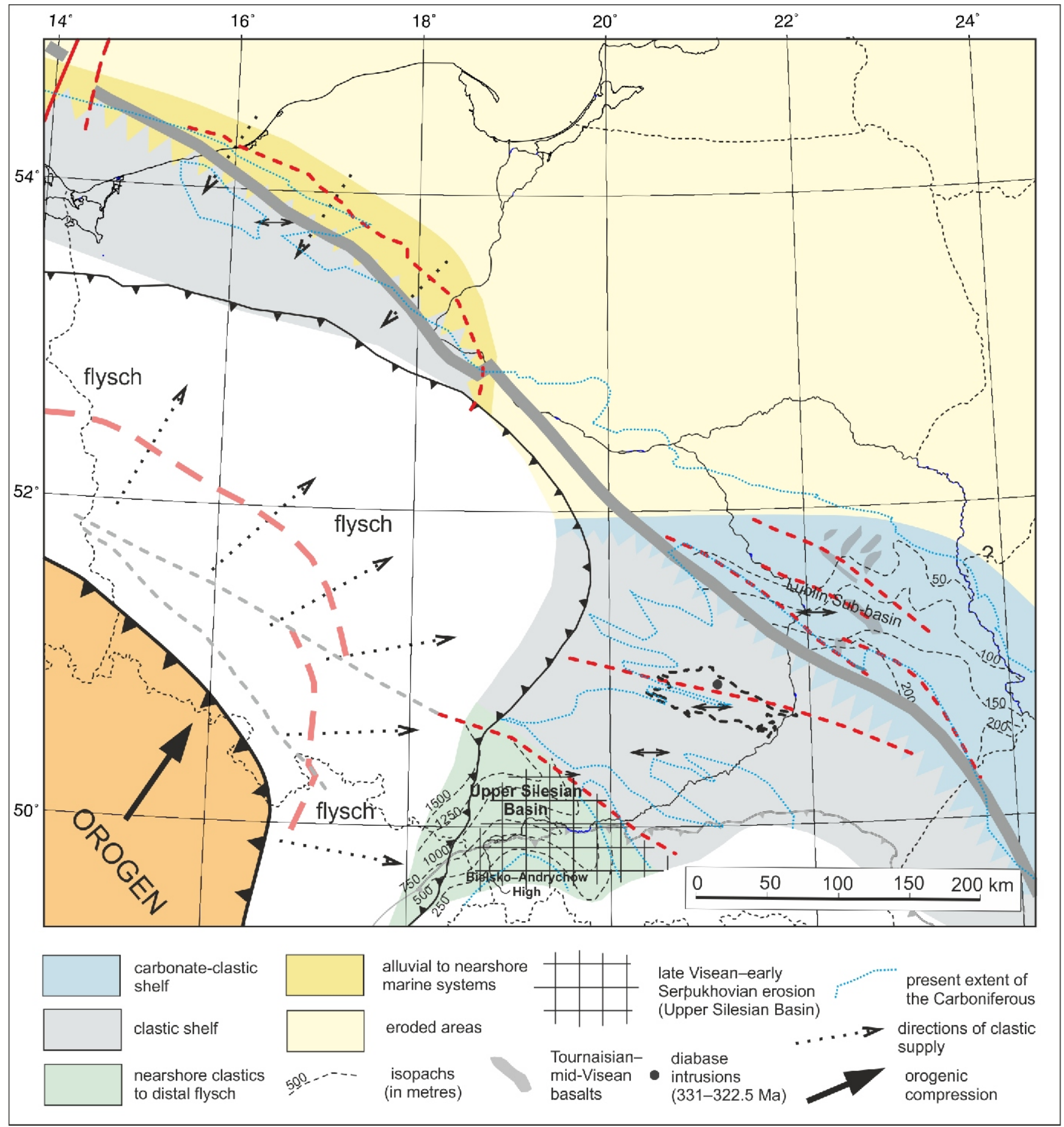

Fig. 8. Late Visean to early Serpukhovian palaeogeography of the Variscan foreland in Poland (modified fig. 9 in Narkiewicz, 2007, based on various sources cited in the text)

Other explanations as in Figure 6

(Westphalian B to Stephanian A-B), up to several hundred metres thick, unconformably onlap various Devonian and Mississippian strata, filling the WNW-ESE striking grabens.

\section{TERMINAL VARISCAN TECTONICS - LATE PENNSYLVANIAN INVERSION}

It is generally accepted that at around the Westphalian-Stephanian boundary (late Moscovian-early Kasimovian) the Variscan foreland area underwent compres- sional deformation with an approximately $\mathrm{N}-\mathrm{S}$ direction of the resulting tectonic shortening. The precise age of these processes is poorly constrained, being defined as pre-Stephanian (late Moscovian) in the USB and pre-Permian in the Płock-Lublin and Pomeranian basins (Narkiewicz, 2007).

The rigid USB basement and its Cambrian to Carboniferous cover were deformed into broad, faulted syn- and antiforms with a general strike close to $\mathrm{E}-\mathrm{W}$, with amplitudes of the order of 1-2 km (e.g., Kotas, 1994). The magnitude of the late Carboniferous uplift and erosion may be estimated as $2-3 \mathrm{~km}$ in the central part of the basin and $\sim 1 \mathrm{~km}$ in the NE (Belka, 1993). In the 


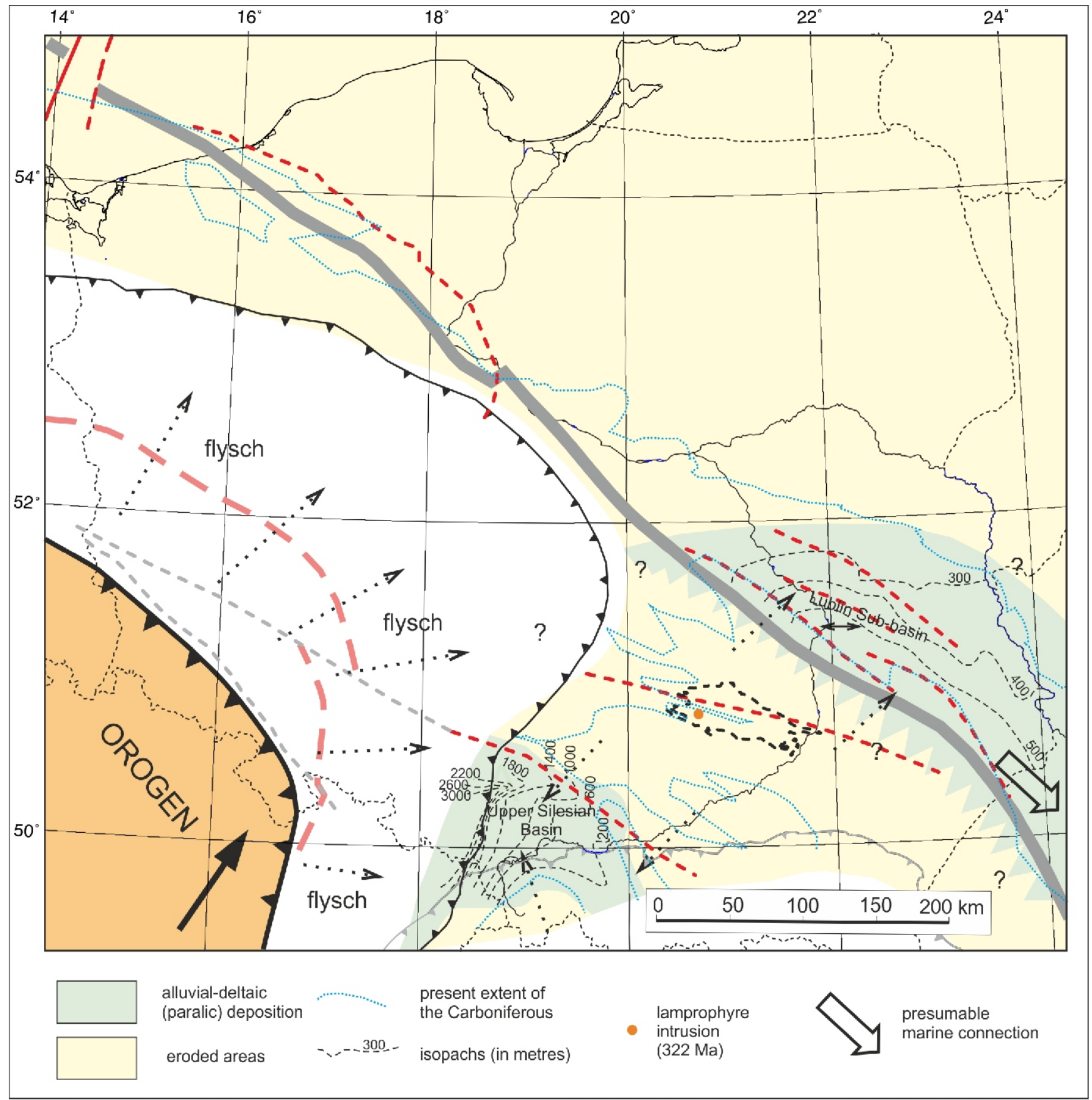

Fig. 9. Mid-late Serpukhovian palaeogeography of the Variscan foreland in Poland (modified fig. 10 in Narkiewicz, 2007, based on various sources cited in the text)

Other explanations as in Figure 6

Kraków-Lublin Fault zone, after an inferred phase of extension during the late Bashkirian-early Moscovian, the axis of compression rotated from initially $\mathrm{N}-\mathrm{S}$ to $\mathrm{NNE}-\mathrm{SSW}$ and even $\mathrm{NE}-\mathrm{SW}$. The resulting dextral transpression led to the formation of inverse faults, associated folds and small thrusts (Żaba, 1999).

In the Małopolska Basin area the Variscan compression caused tectonic shortening, the direction of which changed from N-S to NNE-SSW (Lamarche et al., 2003). The compression resulted in the formation of buckle folds striking $110-120^{\circ}$, with a notable southern vergence, and even partly being overturned as in the case of the well-known Śluchowice Fold ex- posed in Kielce (Lamarche et al., 2003; Konon, 2006). Limbs of anticlines are commonly cut by longitudinal, mostly $\mathrm{N}$-dipping reverse faults or even small-scale thrusts developed in less competent marly Upper Devonian strata (i.a. Racki and Zapaśnik, 1979). According to Lamarche et al. (2003) the longitudinal discontinuities may represent inverted normal faults that developed due to the Devonian extension. The Variscan structure of the Małopolska Basin south of the HC Mts. displays faulted folds with an amplitude similar to those in the HC Mts. but with a considerably larger wave-length (Jurkiewicz, 1975; Papiernik et al., 2007; Buła et al., 2008). 


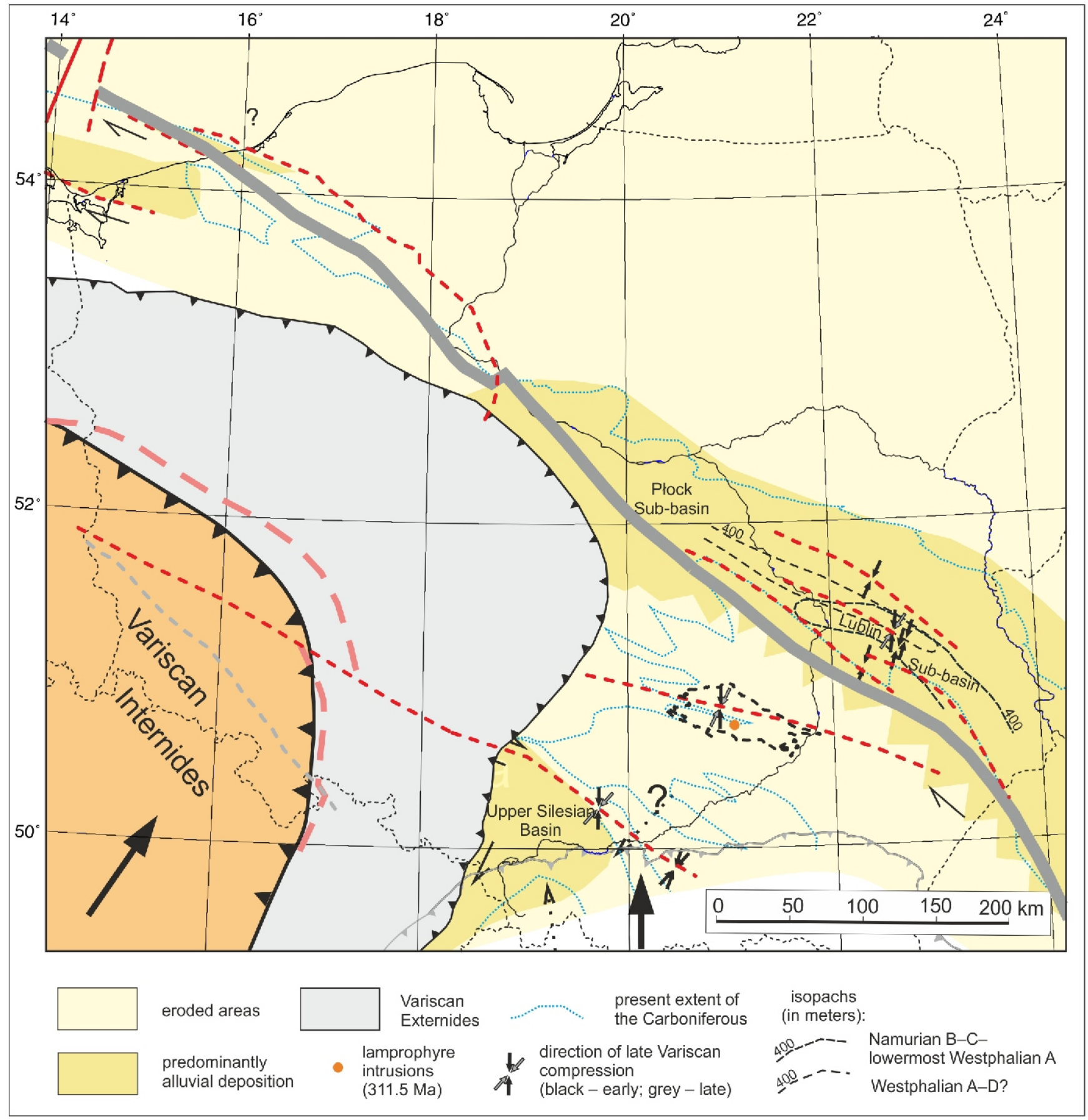

Fig. 10. Mid-Bashkirian to early Kasimovian palaeogeography of the Variscan foreland in Poland (modified fig. 11 in Narkiewicz, 2007, based on various sources cited in the text)

Measured directions of late Westphalian compression - after Jarosiński in Narkiewicz et al. (2007), Lamarche et al. (2003) and Żaba (1999); other explanations as in Figure 6

Konon (2007) documented two phases of strike-slip deformation in the southern HC Mts. area. Phase I-1, associated with a late-folding or post-folding stage, comprised the generation of $\mathrm{N}-\mathrm{S}$-striking dextral, and NE-SW-striking sinistral faults (NNE-SSW shortening). A later phase I-2 entailed the generation or reactivation of approximately NW-SE striking dextral faults, including the Holy Cross Fault (HCF). This major dislocation whose right-lateral strike-slip mode was proposed by Brochwicz et al. (1983) forms an up to $10 \mathrm{~km}$ wide zone of mostly $\mathrm{N}$-inclined reverse faults. These compose a complex positive flower-structure resulting from dextral transpression (Pożaryski et al., 1992; Lamarche et al., 2003), the amplitude of tectonic inversion and associated erosion being up to $4 \mathrm{~km}$. The Variscan structural style of the southern part of the Łysogóry Basin is similar to that in the adjoining ( $\mathrm{HC} \mathrm{Mts.)} \mathrm{part} \mathrm{of} \mathrm{the}$ Małopolska Basin (Mizerski, 1995; Lamarche et al., 2003).

The results of palaeomagnetic studies impose rather wide constraints on the timing of the Late Paleozoic deformation in the HC Mts. - from the Visean, when an early folding phase occurred, to the early Permian marking the termination of the 
Variscan tectonism (Lamarche et al., 2003; Szaniawski, 2008). Thus, the deformation could have started near the Visean -Serpukhovian boundary under a compressional regime which led to uplift and erosion of the Małopolska Basin (Fig. 9). Later, probably during the late Pennsylvanian, the main phase of tectonic shortening and associated deformation occurred.

The regional strike of the late Carboniferous structure of the Płock-Lublin Basin changes from NW-SE in the NW and central segments to NNW-SSE in the south-east (Fig. 3). The Radom-Kraśnik Elevation (RKE) is characterized by the strongest deformation and highest inversion magnitude with not less than $3 \mathrm{~km}$ of a total uplift and associated erosion of the Carboniferous and Devonian strata. The RKE is cut by longitudinal nearly vertical and steep inverted faults, in several cases forming positive flower structures suggestive of transpression (Krzywiec, 2007: fig. 12, 2009: fig. 9).

Recently, Krzywiec et al. (2017a) interpreted the RKE as a thin-skinned fold-and-thrust belt with ?Ediacaran to Devonian strata deformed into a NNE-vergent stack of thrust units. This concept, alluding to the controversial model of the Lublin Sub-basin as a piggy-back passive syncline (Antonowicz et al., 2003) raises many questions, however, and will be addressed separately in the "Discussion" chapter below.

The strongest Variscan deformation in the Lublin Sub-basin is related to longitudinal belts associated with the Stężyca-Mełgiew Central Elevation (Narkiewicz et al., 2007) and the Kock Fault Zone (KFZ). The first structure is situated in the axial part of the basin and comprises a chain of elongated anticlines of amplitude up to $1.5 \mathrm{~km}$ flanked by inverse faults and small thrusts composing positive flower structures. These are probably aligned above a steep basement fault, being detached from its plane by ductile Silurian shales and Frasnian evaporites (Krzywiec, 2007; Narkiewicz et al., 2007).

The KFZ, being internally complex and variable along strike, was developed above the older basement-rooted discontinuity (see above; Tomaszczyk and Jarosiński, 2017). Following the Bretonian uplift, the Hrubieszów Elevation was only slightly reactivated during Late Carboniferous tectonism. In the central segment of the KFZ the elevation formed a rigid buttress for a NE-vergent thrust rooted in Silurian shales. Along the frontal part of the thrust, erosion removed Carboniferous and in part Devonian strata up to $3 \mathrm{~km}$ thick while the total maximum dip-slip offset is estimated at up to $3.5 \mathrm{~km}$. The latter number, however, may represent a cumulative effect of thin-skinned thrusting and thick-skinned transpression that may have accompanied the late stage strike-slip regime (Tomaszczyk and Jarosiński, 2017).

In addition to these belts, an exceptionally high degree of tectonic complexity is also noted near the boundary between the SE and central segments of the basin - in the area where the regional strike changes its direction (cf. Fig. 3). In other areas, the seismic sections show some subordinate inverted faults and minor thrusts with small vertical throws, of various but mostly NE vergence. Partly, and in some cases questionably (see the "Discussion" below), these structures extend in seismic sections down to strata-parallel detachment planes in the Silurian shaly succession (Tomaszczyk, 2016; Kufrasa et al., 2017, 2019).

The SE segment of the Lublin Sub-basin differs from its remaining part in its NNW-ESE regional strike (Fig. 3) and, above all, in the magnitude of Variscan deformation being smaller relative to that of the Bretonian (except for the SW basin margin). For example, the Serebryszcze and Białopole faults (Narkiewicz et al., 2015), which can be regarded as the SE extension of the KFZ (see above), have a clear Bretonian imprint while their Variscan reactivation in a strike-slip regime is either absent (Białopole) or moderate (Serebryszcze; Narkiewicz et al., 2015). Also, the characteristic fault-bounded anticlines are missing here as are larger reverse faults and thrusts. Along the NE tectonic boundary of the RKE and in the adjoining part of the Lublin Basin, basement-rooted reverse faults are accompanied by secondary reverse faults and small thin-skinned thrusts with a NE and partly SW vergence (Krzywiec, 2007: fig. 7, 8, 2009: fig. 13; Narkiewicz et al., 2015).

The tectonic style of the Variscan deformation in the Pomeranian Basin is poorly known. Based on observations of borehole cores, a dextral transpressive and thrust regime was postulated by Żaba and Poprawa (2006).

\section{RESPONSE OF THE VARISCAN FORELAND TO OROGENIC PROCESSES}

The tectono-sedimentary evolution of the Variscan foreland in Poland can be explained in terms of a response to tectonic processes taking place along the active southern margin of Euramerica between the Early Devonian and late Pennsylvanian (Narkiewicz, 2007). In particular, during the successive stages of its development, the foreland and its constituent depocentres were variably affected by tectonic forces emanating from the Western and Central European Variscan orogenic zone and from its hypothetical extension towards the east. The former influence will be analysed by considering primarily the evolution of the Bohemian Massif (Schulmann and Gayer, 2000; Mazur et al., 2006, 2010a). On the other hand, the influence of the SE branch of the Variscan Belt can be inferred from the tectonic evolution of the Black Sea region (recently summarized by Okay and Topuz, 2017), and, indirectly, from the EEP development. With regard to the latter, particular attention will be paid to a major late Paleozoic tectonic structure - the Pripyat-Dnieper-Donets (PDD) rift system (Stephenson et al., 2006). Its development is here believed to record evolving far-field stresses generated in the south (Narkiewicz, 2007).

When analyzing the orogen-foreland relationship, particular importance should be attributed to the Upper Silesian Basin the foredeep basin formed adjacent to the advancing Moravian-Silesian orogenic prism. Starting from the late Visean and until the late Pennsylvanian the USB sedimentary fill was a sensitive recorder of orogenic processes. In the remaining foreland area the response to orogenic compression along the Variscan belt was more indirect and thus more disputable.

The extensional regime prevailing in the Polish part of the southern Euramerica margin during most of the Devonian can be explained by slab-pull forces related to the $\mathrm{N}$-directed subduction of the Rheic oceanic plate. Most probably, these forces were responsible for the Emsian initiation of the narrow Rhenohercynian Ocean and its eastward extension - the back-arc basin in the western part of the Brunovistulian Plate (Fig. 11; Ziegler, 1990; Franke, 2000; Kalvoda, 2002). The same mechanism may explain the development of the PDD rift system farther to the east (Fokin et al., 2001). The Frasnian tectonic subsidence pulse and the Famennian phase of a maximum subsidence in the Lublin Sub-basin correlate with the inception of rifting and with the main rifting stage in the Pripyat Trough, respectively (Kusznir et al., 1996; Narkiewicz and Narkiewicz, 2008). This suggests a common extensional mechanism of the subsidence acceleration, connected probably with intensified subduction processes and related slab-pull forces along the southern margin of Euramerica. 
During most of the Devonian the foreland evolution appears to have been unrelated to the tectonic regime of the West and Central Sudetic domain. The collisional Eo-Variscan tectonics in the Central Sudetes around the Middle/Late Devonian boundary (Mazur et al., 2006, 2010a) did not resonate in the contemporaneous foreland basins. This negative evidence may imply a large distance and/or mechanical decoupling between the Sudetic terranes and the Euramerica plate.

The extensional Devonian regime was interrupted by the Bretonian tectonism near the beginning of the Carboniferous. Particularly strong vertical block movements in the Lublin Basin were controlled by a compressional stress regime with a dextral transpression component (Tomaszczyk and Jarosiński, 2017). The Bretonian tectonism may have been related to accelerated collisional processes along the Euramerica margin. The closure of the Rhenohercynian Basin in the Rhenish area started in the Late Devonian with the oldest flysch deposits (Kulm greywackes) known from the Frasnian (Franke, 2000). In the Sudetic realm the Famennian was a time of a convergence of the west and central Sudetic terranes leading to closure of the Saxo-Thuringian Basin. More or less simultaneously, closure of the East Sudetic back-arc basin started (Mazur et al., 2006, 2010a). These processes collectively testify to an intensification of orogenic collision in the west-central European sector of the southern Euramerica margin late in the Devonian. The compressional stresses were transmitted to the north and east into the foreland area, leading to the Bretonian vertical block movements concentrated along zones of crustal weakness such as the KLF zone the TTZ (?) and the Kock Fault Zone. At the same time, evidence of Bretonian compression is missing from the Pripyat Trough, which suggests that the inner parts of the EEP were not affected by collisional processes along the southern Euramerica margin, particularly along its Black-Sea sector.

After the Bretonian deformation episode, an extensional regime and related magmatism dominated the foreland area during most of the Tournaisian to mid-Visean. By contrast, in the Sudetes, a compressional regime continued during the Tournaisian and early Visean, with ongoing convergence of west and central Sudetic terranes and the development of an accretionary wedge above the Brunovistulian Plate which was being obliquely subducted westwards (Fig. 11; Schulmann and Gayer, 2000; Mazur et al., 2006, 2010a). In the mid-Visean the West Sudetes were uplifted and subjected to extensional collapse, this being accompanied by an inception of granitoid plutonism and initiation of the pull-apart Intra-Sudetic Basin.

In the foreland area the most active igneous processes, known from the late Tournaisian-early Visean of the Lublin Sub-basin (Fig. 7), correspond to the latest stage of heterochronous magmatic activity starting in the Givetian in the Peri-Caspian Depression in the east, in the early Frasnian of the Donbas area and in the early Famennian to (?) early Tournaisian of the Pripyat Trough in the west. Tectonic quiescence in the Tournaisian and earliest Visean in the PDD was followed by late early Visean extension and associated magmatism. The foreland extension was probably due to slab-pull forces transmitted from the ongoing subduction of the oceanic plate beneath the Black Sea sector of the Euramerica margin.

Intensified Gondwana-Euramerica collision in the late Visean-early Serpukhovian resulted in accelerated progradation of the flysch greywackes in the Rhenisch area and also in the Wielkopolska externides (Ricken et al., 2000; Mazur et al., 2010b). In the West and Central Sudetes, ongoing processes of granitoid plutonism were accompanied by high-temperature and low-pressure metamorphism and continuing development of the Intra-Sudetic Basin. In the East Sudetes the collisional processes were reflected in increased rates of uplift and exhumation of internal Moldanubian units. Between 340 and $330 \mathrm{Ma}$ the Moravian-Silesian accretionary prism underwent vertical extrusion, extension and thrusting onto the eastern foreland. The oldest evidence of synorogenic flysch deposition appeared in the mid-Visean in Moravia (Jirásek et al., 2018), and in the late Visean in the USB. This indicates that during that time the USB area was incorporated into a foredeep basin in front of the Moravian-Silesian orogenic wedge prograding to the NE. This is also reflected in the tectonic subsidence curves, which show a steeper slope in the Asbian, marking the onset of a flexural response of the Brunovistulian Plate under the orogenic load (Fig. 5). In the Namurian A (Serpukhovian) the central Sudetic massif was approaching its present position relative to Brunovistulicum.

Renewed subsidence in the Lublin Sub-basin and resulting encroachment of marine transgression were coeval with the onset of the accelerated subsidence in the late Visean and Serpukhovian of the Dniepr-Donets Basin. This may indicate that the EEP area was still influenced by an extensional regime which continued longer than in the western-central European segment of the Variscan belt. Alternatively, the subsidence was an effect of orogenic compression leading to lithospheric-scale buckling (Nikishin et al., 1996) or of a strike-slip/pull-apart regime generated along crustal weakness zones by compressional forces from the south. In the Black Sea region the southern BASSAC belt was affected by intense low pressure-high temperature metamorphism and granitic plutonism (Okay and Topuz, 2017), comparably to the West and Central Sudetes.

As a result of the early Serpukhovian regression, erosional or alluvial-deltaic conditions prevailed in the foreland area during the mid-late Serpukhovian (Fig. 9). This prominent palaeogeographic change has no obvious explanation in tectonic processes observed in the Bohemian Massif and in the PDD. Probably, in addition to a general tendency for compressionally-induced foreland uplift, the early-mid Serpukhovian glacioeustatic lowstand (Bishop et al., 2009) may also have played a part. In the USB area, flysch successions prograded eastwards during flexural foredeep development indicating an ongoing process of orogenic prism advancement. The distinct Lublin depocentre is here interpreted in terms of a pull-apart regime (Żelichowski, 1987; Narkiewicz et al., 1998; Narkiewicz, 2007). Dextral strike-slip movement may have been transmitted by the TTZ from the orogenic compression zone in the south and was distributed among TTZ-parallel discontinuities such as the Kock Fault Zone, the Kazimierz-Ursynów Fault and the Izbica-Zamość Fault (Figs. 3 and 9).

The late Visean-late Serpukhovian phase of the accelerated foredeep subsidence in the USB ended with the earliest Pennsylvanian gap (early Bashkirian). This episode of widespread non-deposition and minor erosion (Fig. 4) coincided with the glacio-eustatic lowstand which may have been superimposed on a tectonic standstill separating two phases of orogenic compression. The ensuing rearrangement of the depocentres of the USB and Płock-Lublin Basin may have been associated with a change in tectonic convergence pattern along the Euramerica margin. The last collisional event in the Black Sea region - between the accreted BASSAC belt and the MOIS continental margin - occurred near the Mississippian-Pennsylvanian boundary, and since that time the newly established Euramerican margin faced the Palaeotethys ocean in the south (Okay and Topuz, 2017). By contrast, the collision between Euramerica and Gondwana continued in the West-Central European Variscides. 

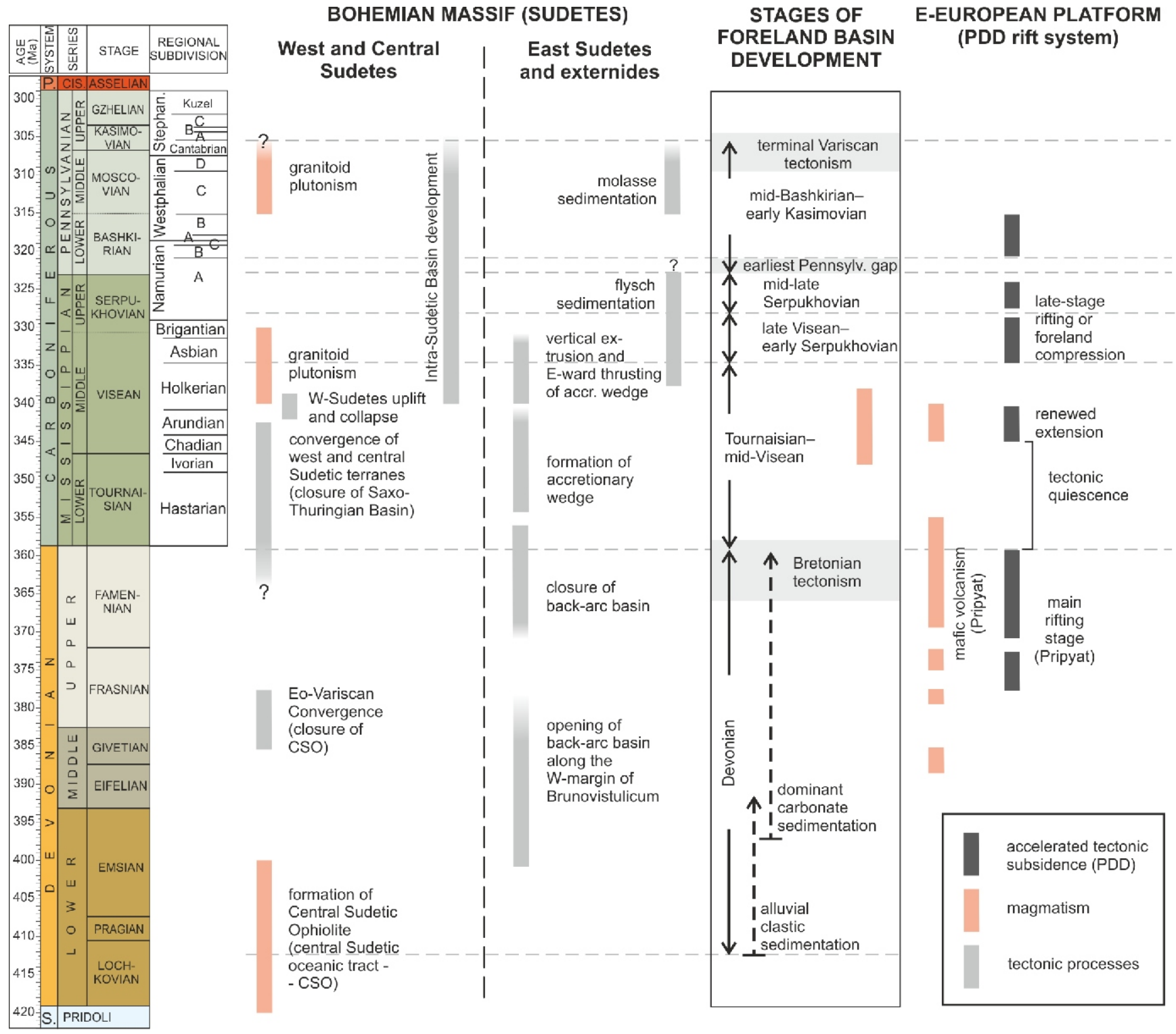

Fig. 11. Correlation of the Variscan foreland developmental stages with the Devonian-Carboniferous tectonic and magmatic processes in the Sudetes and Pripyat-Dnieper-Donets (PDD) rift system (compiled from various sources cited in the text)

The eastwards migration of the USB depocentre during the mid-Bashkirian to Moscovian relative to its late Visean-Serpukhovian location is consistent with the characteristic foredeep-basin shape of the subsidence curve (Fig. 5). Both observations suggest reactivated flexural bending of the lower Brunovistulian Plate in response to a successive phase of the orogenic prism advance towards the NE. The late Moscovian erosional/nondepositional episode before the end of the Moscovian basin development may be correlated with a phase of moderate tectonic deformation, the "Leonian" tectonic event. This is widely noted in the Bohemian Massif area, for instance in the Pilsen-Trutnov Basin Complex comprising the Intra-Sudetic Basin, where it is represented by a gap in sedimentation lasting $\sim 3.5 \mathrm{Ma}$ (Opluštil et al., 2016).

In the Płock-Lublin Basin the apparent control of migrating depocentre geometry by parallel longitudinal faults suggests a pull-apart regime related to a (dextral?) strike-slip movement along the TTZ (Żelichowski, 1987; Narkiewicz et al., 1998). On the other hand, the tectonic activity of the Kock Fault Zone
(KFZ), particularly well-documented for the Namurian, is reflected in reduced sediment thickness on the more stable Hrubieszów Elevation contrasting with the depocentre adjoining it to the SW (Waksmundzka, 2010). Similarly, the local depocentres in the Pomeranian Basin may had been formed in a pull-apart regime related to strike-slip activity along the TTZ (Z̈elichowski, 1987). As during the late Visean-late Serpukhovian stage, the strike-slip displacement along the TTZ may have been the effect of compressional stress transmitted from the southern orogenic belt where tectonic shortening continued after the mid-Carboniferous collisional event (Okay and Topuz, 2017). This interpretation is consistent with the dextral transpressional deformation observed along the Kraków-Lubliniec Fault (Żaba, 1999).

Near the Moscovian-Kasimovian boundary the last episodes of tectonic shortening occurred in the Western and Central European Variscides during the terminal events of continental collision. By the end of the Moscovian the West and Central Sudetes were finally moulded in an embayment of the 
Euramerica margin west of Brunovistulicum. During the final phase of this process the Variscan Internides moved obliquely northeastwards along the Moravian-Silesian suture zone, while $\mathrm{N}-\mathrm{S}$ to NE-SW-directed tectonic shortening affected the entire foreland area. In the internal parts of the EEP, particularly in the PDD belt, evidence of compressional deformation is missing. This points to a decisive role of Gondwana-Euramerica collision processes in the west-central European segment of the Variscan orogenic belt for the end-Carboniferous deformation in the foreland area, while the Black Sea segment was probably less active at that time.

\section{DISCUSSION}

Recently, the style and magnitude of Variscan tectonism in SE Poland have been reinterpreted by Krzywiec et al. (2017a, b) and in further publications by Mazur et al. (2018), Kufrasa et al. $(2017,2019)$, which in turn inspired a new approach to the regional subdivision of Variscan Poland (Aleksandrowski and Mazur, 2017). The concepts proposed in these publications refer to the idea of the Lublin Sub-basin being a passive syncline bounded by zones of duplexes along the RKE and KFZ, and thrust northeastwards in a piggy-back fashion (Antonowicz et al., 2003; Antonowicz and Iwanowska, 2004). This idea, drawing on analogies with the Appalachian Orogen, assumed the location of the Variscan orogenic front along the KFZ and implied its coupling with the internal parts of the orogen by means of a master detachment. After its proposal, it became a subject of a lively discussion and was contested in several papers (Dadlez, 2003, Krzywiec and Narkiewicz, 2003; Narkiewicz, 2003; Krzywiec, 2009). The concept, further developed by Krzywiec et al. (2017a) based on new seismic data, is here referred to as the "coupled model" of the Variscan foreland, in opposition to the "decoupled model" supported by the present author (Narkiewicz, 2007, this paper; Fig. 12A). In the "decoupled model" the orogenic front runs much closer to the Variscan Internides (Fig. 3). The Variscan foreland as defined here underwent the final Late Carboniferous deformation due to orogenic compression transmitted from the orogen in the south, partly through major crustal-scale subvertical fault zones striking roughly NW-SE. The latter included the KLF, HCF and TTZ, around which the most-deformed compressional and transpressional structures are centered (Narkiewicz, 2007).

A key element of the recent version of the "coupled model" is the interpretation of the RKE as a thin-skinned fold-and-thrust belt emplaced onto the margin of the EEC, based mainly on the seismic reflection PL-5100 and 5000 profiles (Krzywiec et al., 2017a; see the location in Fig. 3). This belt, comprising an up to $12 \mathrm{~km}$ thick stack of NNE-vergent thrusts composed of the ?Ediacaran to Devonian strata, is supposed to extend from the Grójec Fault in the NW, and towards the SE to Ukraine (Fig. 12B). Consequently, the RKE represents an orogenic front where a deep-rooted detachment rises up to the pre-Permian-Mesozoic unconformity. The thrusts forming the RKE converge to the SW into a basal detachment near the base of the Ediacaran strata. To the east the master thrust ascends to a base of Silurian shales forming a complex triangle zone due to a buttressing effect of the EEC basement slope.

Krzywiec et al. (2017a) concluded that their seismic data do not image any basement-rooted subvertical discontinuities related to the RKE or TTZ as interpreted by Narkiewicz et al. (2015). On the contrary, they suggested that the Łysogóry and Małopolska blocks were thrust onto the East European craton margin. In the subsequent paper Krzywiec et al. (2017b: fig. 3) reinterpreted the POLCRUST-01 profile, placing the master thrust above the EEP basement in the RKE and farther to the
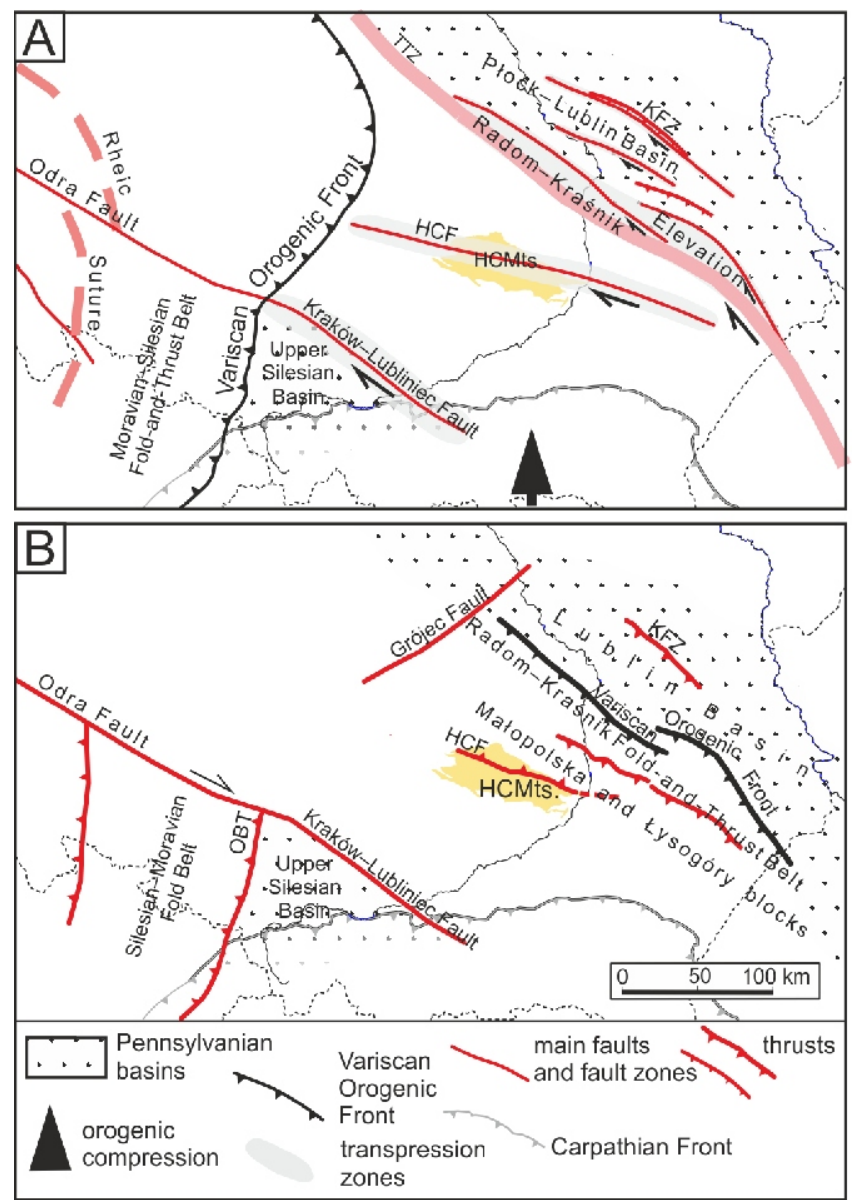

Fig. 12. Schematic sketches showing comparison of tectonic concepts of the Variscan foreland in Poland: (A) according to Narkiewicz (2007, this paper) and (B) according to Krzywiec (2017a, b) and Mazur et al. (2018)

\section{HCF - Holy Cross Fault, HCMts. - Paleozoic core of the Holy Cross Mountains, KFZ - Kock Fault Zone, OBT - Orlova-Boguszowice Thrust}

SW beyond the HCF(cf. Narkiewicz et al., 2015). The same position of the main basal detachment is shown by Mazur et al. (2018: fig. 7) in their interpretation of the regional SW-NE cross-section extending from the $\mathrm{HC}$ Mts. to the KFZ. According to their concept, the stack of thrusts underlying the RKE and most of the Łysogóry Block merges to the SW beneath the HC Mts. into a single detachment plane above the crystalline basement top.

At the outset of the following discussion, there should be stressed the difference between the documentation of the transcurrent model of the TTZ and ERK-related deformation (Narkiewicz et al., 2015) on one hand, and the evidence supporting the rival hypothesis by Krzywiec et al. (2017a) on the other. In the first publication the interpretation is documented with a seismic record showing reflections related to the architecture of the basement and its sedimentary-volcanic cover. On the other hand, the validity of the seismic interpretation of the thin-skinned thrust-and-fold belt by Krzywiec et al. (2017a: fig. 5) is hard to assess as they show only line drawings of their deep seismic lines PL-5000 and PL-5100, not providing an uninterpreted seismic record. Two shallow commercial sections illustrated by these authors (their fig. 6) show vaguely imaged seismic reflectors with an interpretational overlay that renders any independent verification difficult (by contrast with e.g. seis- 
mic material from the same area earlier illustrated and interpreted differently by Krzywiec, 2009: fig. 13). Clues to such verification are offered by the profile PL-5100 reprocessed by Malinowski (2016), showing that the crystalline basement top is poorly traceable beyond the TTZ (Narkiewicz and Petecki, 2019). On the other hand, Kufrasa et al. (2017) stress the poor quality of seismic imaging in the commercial profiles crossing the RKE-Lublin Basin boundary where their tectonic interpretations of stacked thrusts are of a "conceptual character". Notably, this reservation disappears in the later version of the paper (Kufrasa et al., 2019).

Krzywiec et al. (2017b) reinterpreted the POLCRUST-01 line in the spirit of their fold-and-thrust RKE model. They discarded the interpretation of the vertical TTZ discontinuity by Narkiewicz et al. (2015) mainly based on the results of modeling the seismic record of a parallel (unnamed) commercial cross-section. According to these authors the discontinuity of the basement top is a seismic artifact caused by a lateral contrast in sediment density. A closer look at their modeling results (Narkiewicz and Petecki, 2019) shows, however, that these are: (1) based on a questionable tectonic interpretation of the "model cross-section", and (2) scarcely comparable to the original seismic record as provided by Narkiewicz et al. (2015). In summary, the documentation presented so far by Krzywiec et al. (2017a, b) is unsatisfactory, and their hypothesis of the "Radom-Kraśnik Fold-and-Thrust Belt" - if valid - must await future confirmation by more data, or at least a better documentation of previous evidence.

One may claim, however, that even if the presence of an RKE fold-and-thrust belt and associated Variscan Front is questionable, there is still much evidence for compressional deformation in the area discussed, including the Lublin Sub-basin itself. Moreover, compressional structures, thrusts included, may have been potentially constrained by zones of elevated basement forming a backstop, as conceived by Krzywiec et al. (2017a). Considering the above arguments in a broader regional context of the Variscan foreland it is clear that in fact the most deformed belts are associated with major long-lived crustal discontinuities: the Kraków-Lubliniec Fault (KLF), HCF, TTZ (and associated RKE) and KFZ. The "backstop model" is plausible in the case of limited thrusting in the KFZ belt, associated with a distinct basement step (Tomaszczyk and Jarosiński, 2017). On the other hand, it seems to be inconsistent with the concept of a basement top sloping gradually at a low angle across the RKE, as assumed by Krzywiec et al. (2017a, b) and Mazur et al. (2018).

The Lublin Sub-basin is regarded as a passive syncline both by Antonowicz et al. (2003) and Krzywiec et al. (2017a) although the latter authors cast doubt on its piggy-back displacement and prefer to explain its geometry as resulting from both flanks being upturned by triangle zones (passive-roof duplexes). According to the present author the post-inversion geometry of the basin may indeed be conceived as a passive synform flanked by transpressionally elevated RKE and KFZ zones, and not by purely compressional duplexes.

The difference in tectonic style between the SE and NW segments of the basin (see the section above on the terminal Variscan tectonics) may be related to an inherited pattern of crustal discontinuities, particularly the TTZ. It may be noticed that the latter zone and the Izbica-Zamość fault change strike by bending westwards near the central segment of the basin (Fig. 12A). Thus, assuming an overall $\mathrm{N}-\mathrm{S}$ direction of regional Variscan compression, it is to be expected that along pre-existing WNW-ESE striking faults the compressional component of deformation will be more pronounced. In contrast, in the SE segment, the NNW-SSE striking structural grain of the basement will impart a strike-slip or transpressional deformation in the sedimentary cover, rather than a purely compressional one. Indeed, it may be observed that the magnitude of thrusting attains its maximum in the central segment of the basin (Tomaszczyk, 2016; Tomaszczyk and Jarosiński, 2017), as predicted above. At the same time the scale of reverse-faulting and thrusting is much smaller in the SE segment (Kufrasa et al., $2017,2019)$, even smaller than that of the earlier Bretonian deformation.

An important question related to the "coupled model" is the alleged master detachment linking the internal orogen (Bohemian Massif) with the Radom-Krasnik Fold-and-Thrust Belt (Krzywiec et al., 2017a). Such a structure was invoked already by Lamarche et al. (2003) who speculated on dysharmonic deformation of the Devonian-Carboniferous strata in the HC Mts., related to a basal detachment. Nevertheless, such a structure has not been documented so far, its presence being doubtful on the following grounds:

(1) during the late Variscan deformations the basement of the Variscan foreland between the Moravian-Silesian belt and the EEP was highly heterogeneous as were the overlying Devonian sediments (Narkiewicz, 2007; see above, the chapter on basement units); it is thus highly improbable that they could serve as a regional detachment horizon;

(2) the basement is apparently downthrown to the NE of the KLF (e.g., Żaba, 1999) thus excluding its role as a backstop for NE-vergent thrusts; also, in the case of the HCF and TTZ, the "backstop geometry" of the basement top is not obvious;

(3) a predominant SW-vergence of the HCF is incompatible with the opposite vergence of the alleged foreland thrusts of the RKE and would require the assumption (and documentation) of a backthrust, thus leading to an overly complicated tectonic model of the $\mathrm{HC}$ Mts.

Krzywiec et al. (2017a) briefly discussed the problem of the transfer of tectonic shortening from the inner parts of the orogen (Bohemian Massif) to the RKE belt and Lublin Basin. They stressed the significance of a master basal detachment but also considered the possible role of dextral strike-slip movements along the Odra and Kraków-Lubliniec faults in generating a localized shortening in the RKE zone (Fig. 12B). While dextral strike-slip movements related to northward compression may have been responsible for the transpressive deformations along the KLF, the relationship of a displacement along this fault to the RKE deformation seems doubtful. The role of the TTZ and associated faults in transferring the compressional stresses to the RKE and parallel faults to the NE is here regarded as much more plausible.

The "coupled model" of the Variscan foreland/orogen has been promptly applied in the publication by Aleksandrowski and Mazur $(2017)^{3}$ as a part of their provocative wholesale revision of the tectonics of extra-Carpathian and extra-Sudetic Poland. Only the part of their ideas that refer to Variscan tectonics will be

\footnotetext{
${ }^{3}$ This short paper is aimed at explaining the controversial "new tectonic solutions" introduced in the atlas edited by Nawrocki and Becker (2017). It may be parenthetically noted that such thorough revision of concepts well-grounded in the Polish regional geology certainly would require more clear definition of the new regional units proposed, not to mention their better substantiation. It should be also based on a comprehensive review and discussion of previous results, and not only on selected publications.
} 
briefly discussed below. Aleksandrowski and Mazur (2017) considerably expand the interpretations by Krzywiec et al. (2017a, b) by including their Radom-Kraśnik Fold-and-Thrust Belt into the much wider concept of a Holy Cross-Radom-Lublin Fold-and-Thrust Belt. Consequently, they follow an earlier idea (Antonowicz et al., 2003), shifting the Variscan Front to the east as far as the KFZ. The inclusion of the HC Mts to the Variscan orogen appears to be based on a selective historical discussion supplemented by some vague statements about a "quite intensely folded" zone and therefore belonging to "the marginal zone of a vast Variscan Orogen". The USB and most of the Małopolska Basin is included within the "Upper Silesian-Małopolska Intramontane Basin" but neither justification of its boundaries nor any information on its development (age of sedimentary fill? sediment source areas? subsidence pattern?) are given by the authors. Most of the Holy Cross-Radom-Lublin Fold-and-Thrust Belt, except for the Lublin Sub-basin (as defined here) is labelled on the attached map (Aleksandrowski and Mazur, 2017: fig. 1) as the "pre-Carboniferous basement of intramontane and foredeep basins affected by a Variscan fold and thrust deformation". From the cited paper it is not clear, however, if an intramontane or foredeep basin is meant in this particular case, what constituted its basin fill and when it was formed.

Concluding the above discussion, the "decoupled model" of the final Variscan foreland deformation is here regarded as better substantiated than the newly proposed "coupled model" which appears to be based mainly on inadequately documented seismic material. The idea of transpressional deformation related to major fault zones seems more plausible, being supported by well-documented seismic data and structural observations from outcrops and boreholes (see section above on terminal Variscan tectonics). Moreover, the latter model is more consistent with our knowledge of the structure and development of the Variscan foreland basins and their basement, provided in this article and in its predecessor (Narkiewicz, 2007). The regional subdivision of the Variscan structures in SE Poland proposed by Aleksandrowicz and Mazur (2017) not only uncritically incorporates and expands the "coupled model", but makes it even more questionable by multiplying inadequately defined regional units, like various configurations of fold and thrust belts and intramontane/foredeep basins.

\section{CONCLUSIONS}

The present study supports the earlier conclusions as to the role played by the pre-existing basement structure (redefined by Narkiewicz and Petecki, 2017) during the development of the Devonian and Carboniferous basins of the Variscan foreland in Poland (Narkiewicz, 2007). In particular, re-activated Caledonian sutures and older crustal-scale fault zones in the EEP controlled the geometry of depocentres and determined zones of the Bretonian (Devonian/Carboniferous) and late Pennsylvanian compressional deformation.

Subsidence was created by forces propagated from the active southern margin of Euramerica. An indirect effect of the far-field stress led to extension during most of the Devonian and Mississippian through slab-pull forces, and to compression during the Bretonian tectonism and late Pennsylvanian inversion, due to collisional events. Only in the case of the USB can the direct effect of the advancing orogenic Moravian-Silesian prism creating a typical foredeep-basin subsidence be demonstrated.
Periodization of the foreland development reflects successive tectonic processes along the southern active margin, mainly accelerated convergence and tectonic standstill, with a more pronounced role of eustatic events particularly during the Devonian and near the Mississippian-Pennsylvanian boundary. Comparison with the tectonic evolution of the Bohemian Massif shows that Eo-Variscan terrane convergence near the Mid-Late Devonian boundary was not reflected in the foreland, thus suggesting a lack of coupling between the Sudetic terranes and the Polish sector of the Euramerica plate. On the other hand, the Bretonian compressional deformation in the foreland may be linked with intensified orogenic convergence in the West-Central European Variscides leading to a closure of the Saxo-Thuringian Basin and East-Sudetic back-arc basin. A widespread stratigraphic gap and ensuing rearrangement of depocentres near the Mississippian-Pennsylvanian boundary may have been associated with termination of the terrane collision in the Black Sea region and ongoing continental collision in the West-Central European Variscides (Okay and Topuz, 2017).

Late Pennsylvanian basin inversion and associated N-E to SW-NE tectonic shortening took place during the final episodes of continental collision in the south. The folding and faulting of the foreland basin-fill was most intense along the former basin boundaries. These were pre-determined by older subvertical crustal-scale discontinuities acting as mechanically weaker zones during both the subsidence and inversion phases. The zones, including the KLF, HCF, TTZ and KFZ, predetermined localization of belts of exceptionally strong compressional deformation with a strike-slip component, including inverse faulting and small-scale thrusting. They also display the highest amplitude of inversion and pre-Permian-Mesozoic erosion. The tectonically elevated basin margins created, particularly in the case of the Lublin Sub-basin, a characteristic synformal structure. Such a concept, termed here the "decoupled model", assumes transmission of compressional stresses from the orogen through displacement along the TTZ and other tectonic zones focusing intense, mostly transpressive deformation. At the same time the remaining basin fill was much more weakly deformed into buckle folds and superimposed inverse to oblique-slip and strike-slip faults.

This critical review and discussion of the new seismic data regarding the deep structure and sedimentary cover tectonics of SE Poland allows us to conclude that the hypothesis of the Radom-Kraśnik Fold-and-Thrust Belt (Krzywiec et al., 2017a) as an external part of the Variscan Orogen seems inadequately substantiated. The new seismic data document compressional deformation, including small thrusts in the RKE and Lublin Sub-basin (Tomaszczyk, 2016; Tomaszczyk and Jarosiński, 2017; Kufrasa et al., 2017, 2019). However, the "coupled model" of the Variscan foreland, assuming a link between the Bohemian Massif and the RKE through a major horizontal detachment, appears questionable. Even more doubtful are implications of this model for the tectonic subdivision of the Variscan structure in Poland proposed by Aleksandrowski and Mazur (2017).

Acknowledgements. The journal reviewers, S. Opluštil (Charles University in Prague) and S. Skompski (Warsaw University) are thanked for their valuable remarks and suggestions. Funding of the present work was provided by the Polish Geological Institute-NRI statutory funds (project no. 61.2905.1801.00.0). J. Turczynowicz is acknowledged for computer drawing of some figures. 


\section{REFERENCES}

Aleksandrowski, P., Mazur, S., 2002. Collage tectonics in the northeasternmost part of the Variscan Belt: the Sudetes, Bohemian Massif. Geological Society Special Publications, 201: 237-277.

Aleksandrowski, P., Mazur, S., 2017. On the new tectonic solutions in "Geological Atlas of Poland" (in Polish with English summary). Przegląd Geologiczny, 65: 1499-1510.

Antonowicz, L., Iwanowska, E., 2004. Thin-skinned nature of the Variscan tectonics in the Lublin area, Poland (in Polish). Przegląd Geologiczny, 52: 128-130.

Antonowicz, L., Hooper, R., Iwanowska, E., 2003. Lublin Syncline as a result of thin-skinned Variscan deformation (SE Poland) (in Polish with English summary). Przegląd Geologiczny, 51: 344-350.

Banka, D., Pharaoh, T.C., Williamson, J.P., TESZ Project Potential Field Core Group, 2002. Potential field imaging of Palaeozoic orogenic structure in northern and central Europe. Tectonophysics, 360:23-45.

Behr, H.-J., Engel, W., Franke, W., Giese, P., Weber, K., 1984. The Variscan Belt in Central Europe: main structures, geodynamic implications, open questions. Tectonophysics, 109: 15-40.

Bełka, Z., 1985. Lower Carboniferous conodont biostratigraphy in the northeastern part of the Moravia-Silesia Basin. Acta Geologica Polonica, 35: 33-60.

Bełka, Z., 1987. The development and decline of a Dinantian carbonate platform: an example from the Moravia-Silesia Basin, Poland. Geological Journal Special Issue, 12: 177-188.

Belka, Z., 1993. Thermal and burial history of the Cracow-Silesian region (southern Poland) assessed by conodont CAI analysis. Tectonophysics, 227: 161-190.

Belka, Z., Narkiewicz, M., 2008. Devonian. In: The Geology of Central Europe (ed. T. McCann), Vol. 1: Precambrian and Palaeozoic: 383-410. Geological Society, London.

Belka, Z., Valverde-Vaquero, P., Dörr, W., Ahrendt, H., Wemmer, K., Franke, W., Schäfer, J., 2002. Accretion of first Gondwana-derived terranes at the margin of Baltica. Geological Society Special Publications, 201:19-36.

Belka, Z., Devleeschouwer, X., Narkiewicz, M., Piecha, M., Rejiers, T.J.A., Ribbert, K.-H., Smith, N.J.P., 2010. Devonian. In: Petroleum Geological Atlas of the Southern Permian Basin Area (eds. J.C. Doornebal and A.G. Stevenson): 71-79. EAGE Publications b.v. (Houten).

Bishop, J.W., Montanez, I.P., Gulbranson, E.L., Brenckle, P.L., 2009. The onset of mid-Carboniferous glacio-eustasy: sedimentologic and diagenetic constraints, Arrow Canyon, Nevada. Palaeogeography, Palaeoclimatology, Palaeoecology, 276: $217-243$.

Brezinski, D.K., Cecil, C.B., Skema, V.W., Stamm, R., 2008. Late Devonian glacial deposits from the eastern United States signal an end of the mid-Paleozoic warm period. Palaeogeography, Palaeoclimatology, Palaeoecology, 268: 143-151.

Brochwicz-Lewiński, W., Pożaryski, W., Tomczyk, H., 1983. Paleozoic strike-slip movements in southern Poland (in Polish with English summary). Przegląd Geologiczny, 31: 651-658.

Buła, Z., Żaba, J., 2005. Pozycja tektoniczna Górnośląskiego Zagłębia Węglowego na tle prekambryjskiego i dolnopaleozoicznego podłoża (in Polish). Przewodnik 76 Zjazdu Polskiego Towarzystwa Geologicznego Rudy k/Rybnika. Polish Geological Institute, Warszawa: 14-42.

Buła, Z., Żaba, J., 2008. Structure of the Precambrian basement of the eastern part of the Upper Silesian block (Brunovistulicum) (in Polish with English summary). Przegląd Geologiczny, 56: 473-480.

Buła, Z., Jachowicz, M., Żaba, J., 1997. Principal characteristics of the Upper Silesian Block and Małopolska Block border zone (southern Poland). Geological Magazine, 134: 669-677.

Buła, Z., Byś, I., Florek, R., Habryn, R., Jachowicz, M., Kwarciński, J., Laskowicz, R., Liszka, B., Madej, K., Maksym, A., Markowiak, M., Pietrusiak, M., Probulski, J.,
Ryłko, W., Salwa, S., Sikora, R., Staryszak, G., Tabol-Wójcik, P., Tomaś, A., Zacharski, J., 2008. Geological-structural atlas of the Palaeozoic basement of the Outer Carpathians and Carpathian Foredeep. Polish Ministry of Environment, Warsaw.

Buła, Z., Habryn, R., Jachowicz-Zdanowska, M., Żaba, J., 2015. The Precambrian and Lower Palaeozoic of the Brunovistulicum (eastern part of the Upper Silesian Block, southern Poland) the state of the art. Geological Quarterly, 59 (1): 123-134.

Cocks, L.R.M., Torsvik, T.H., 2006. European geography in a global context from the Vendian to the end of the Palaeozoic. In: European Lithosphere Dynamics (eds. D.G. Gee and R.A. Stephenson). Geological Society Memoirs, 32: 83-95.

Dadlez, R., 2003. Lublin Syncline as a result of thin-skinned Variscan deformation (SE Poland) - debate (in Polish). Przegląd Geologiczny, 51: 729-730.

Dadlez, R., Kowalczewski, Z., Znosko, J., 1994. Some key problems of the pre-Permian tectonics of Poland. Geological Quarterly, 38 (2): 169-190.

Dadlez, R., Grad, M., Guterch, A., 2005. Crustal structure below the Polish Basin: is it composed of proximal terranes derived from Baltica? Tectonophysics, 411: 111-128.

De Vleeschouwer, D., Da Silva, A.C., Boulvain, F., Crucifix, M., Claeys, P., 2012. Precessional and half-precessional climate forcing of Mid-Devonian monsoon-like dynamics. Climate of the Past, 8: 337-351.

Dudek, A., 1980. The crystalline basement block of the Outer Carpathians in Moravia: Bruno-Vistulicum. Rozpravy Československé Akademie Věd - Řada Matematických a Prírodních Věd, 90: 1-85.

Finger, F., Hanzl, P., Pin, C., von Quadt, A., Steyrer, H.P., 2000 The Brunovistulian: Avalonian Precambrian sequence at the eastern end of the Central European Variscides? Geological Society Special Publications, 179: 103-112.

Fokin, P.A., Nikishin, A.M., Ziegler, P.A., 2001. Peri-Uralian and Peri-Palaeo-Tethyan Rift systems of the East European Craton. Peri-Tethys Memoir 6, Mémoires du Muséum National d'Histoire Naturelle, 186: 347-368.

Franke, W., 2000. The mid-European segment of the Variscides: tectonostratigraphic units, terrane boundaries and plate tectonic evolution. Geological Society Special Publications, 179: 35-61.

Franke, W., Cocks, L.R.M., Torsvik, T.H., 2017. The Palaeozoic Variscan oceans revisited. Gondwana Research, 48: 257-284.

Gawęda, A., 2007. Variscan granitoid magmatism in Tatra Mountains - the history of subduction and continental collision. AM Monograph, 1: 319-332.

Golonka, J., Gawęda, A., 2012. Plate tectonic evolution of the southern margin of Laurussia in the Paleozoic. In: Tectonics Recent advances (ed. E. Sharkov): 261-282. InTech, Rijeka.

Gradstein, F.M., Ogg, J.G., Schmitz, M.D., Ogg, G.M., 2012. The Geologic Time Scale 2012. Elsevier, Amsterdam.

Gradziński, R., Doktor, M., Kędzior, A. 2005. Sedimentation of the coal-bearing succession in the Upper Silesia Coal Basin: research trends and the current state of knowledge (in Polish with English summary). Przegląd Geologiczny, 53: 734-741.

Jastrzębski, M., 2012. New insights into the polyphase evolution of the Variscan suture zone: evidence from the Staré Město Belt, NE Bohemian Massif. Geological Magazine, 149: 945-963.

Jawor, E., Baran, U., 2004. Geological setting and characteristics of Carboniferous strata in the southern part of the Małopolska block (in Polish with English summary). In: Hydrocarbon Generation Potential of Carboniferous Rocks in the Southern Part of the Upper Silesian and Małopolska Blocks (ed. M.J.Kotarba): 25-48. Geosfera, Kraków.

Jaworowski, K., 2002. Geotectonic significance of Carboniferous deposits NW of the Holy Cross Mts. (central Poland). Geological Quarterly, 46 (3): 267-280.

Jirásek, J., Hylová, L., Sivek, M., Jureczka, J., Martínek, K., Sykorová, I., Schmitz, M., 2013. The Main Ostrava Whetstone: composition, sedimentary processes, palaeogeography and 
geochronology of a major Mississippian volcaniclastic unit in the Upper Silesian Basin (Poland and Czech Republic). International Journal of Earth Sciences, 102: 989-1006

Jirásek, J., Otava, J., Matýsek, D., Sivek, M., Schmitz, M.D. 2018. The radioisotopically constrained Visean onset of turbidites in the Moravian-Silesian part of the Rhenohercynian foreland basin (Central European Variscides). International Journal of Earth Sciences, 107: 711-727.

Jubitz, K.-B., Znosko, J., Franke, D., Garetsky, R., 1986. Southwest border of the East European Platform. Tectonic Map 1:1500 000. IGCP Project 86. Z.G.I. Berlin.

Jurkiewicz, H., 1975. Palaeogeography of the Precambrian and the Palaeozoic in the central part of the Miechów Trough (in Polish with English summary). Biuletyn Instytutu Geologicznego, 283 $1-100$

Kaiser, S.I., Aretz, M., Becker, R.T., 2016. The global Hangenberg Crisis (Devonian-Carboniferous transition): review of a first-order mass extinction. Geological Society, Special Publications 423: 201-222.

Kalvoda, J., 2002. Late Devonian-Early Carboniferous foraminiferal fauna: zonations, evolutionary events, paleobiogeography and tectonic implications. Folia Faculty of Science National University Masaryk, Brunia, Geologia, 39: 1-213.

Kędzior, A., Gradziński, R., Doktor, M., Gmur, D., 2007. Sedimentary history of a Mississippian to Pennsylvanian coal-bearing succession: an example from the Upper Silesia Coal Basin, Poland. Geological Magazine, 144: 487-496.

Konon, A., 2006. Buckle folding in the Kielce Unit, Holy Cross Mountains, central Poland. Acta Geologica Polonica, 56: 375-405.

Konon, A., 2007. Strike-slip faulting in the Kielce Unit, Holy Cross Mountains, central Poland. Acta Geologica Polonica, 57: 415-441.

Kotas, A., 1994. Coal-bed methane potential of the Upper Silesian Coal Basin, Poland. Prace Państwowego Instytutu Geologicznego, 142: 1-81

Kroner, U., Mansy, J-L., Mazur S., Aleksandrowski, P., Hann, H.P., Huckriede, H., Lacquement, F., Lamarche, J., Ledru, P. Pharaoh, T.C., Zedler, H., Zeh, A., Zulauf, G., 2008. Variscan tectonics. In: The Geology of Central Europe (ed. T. McCann), 1: Precambrian and Palaeozoic: 559-664. The Geological Society, London.

Krzemińska, E., Krzemiński, L., 2019. Magmatic episodes in the Holy Cross Mountains, Poland - a new contribution from multi-age zircon populations. Biuletyn Państwowego Instytutu Geologicznego, 474: 43-58.

Krzemińska, E., Krzemiński, L., Petecki, Z., Wiszniewska, J., Salwa, S., Żaba, J., Gaidzik, K., Williams, I.S., Rosowiecka, O., Taran, L., Johansson, A., Pécskay, Z., Demaiffe, D., Grabowski, J., Zieliński, G., 2017. Geological map of crystalline basement in the Polish part of the East European Platform 1:1 000 000. Polish Geological Institute, Warszawa

Krzywiec, P., 2007. Tectonics of the Lublin area (SE Poland) - new views based on results of seismic data interpretation (in Polish with English summary). Biuletyn Państwowego Instytutu Geologicznego, 442:1-18

Krzywiec, P., 2009. Devonian-Cretaceous repeated subsidence and uplift along the Teisseyre-Tornquist zone in SE Poland insight from seismic data interpretation. Tectonophysics, 475 142-159.

Krzywiec, P., Narkiewicz, M., 2003. O stylu strukturalnym kompleksu dewońsko-karbońskiego Lubelszczyzny w oparciu o wyniki interpretacji danych sejsmicznych (in Polish). Przegląd Geologiczny, 51: 795-797.

Krzywiec, P., Mazur, S., Gagała, Ł., Kufrasa, M., Lewandowski, M., Malinowski, M., Buffenmyer, V., 2017a. Late Carboniferous thin-skinned compressional deformation above the SW edge of the East European craton as revealed by seismic reflection and potential field data: Correlations with the Variscides and the Appalachians. GSA Memoir, 213: 353-372.

Krzywiec, P., Gągała, Ł., Mazur, S., Słonka Ł., Kufrasa, M. Malinowski, M., Pietsch, K., Golonka, J., 2017b. Variscan de formation along the Teisseyre-Tornquist Zone in SE Poland:
Thick-skinned structural inheritance or thin-skinned thrusting? Tectonophysics, 718: 83-91.

Kufrasa, M., Krzywiec, P., Słonka Ł., 2017. Model paleozoiczne ewolucji tektonicznej SE Polski (blok radomsko-kraśnicki i basen lubelski) w oparciu o wyniki interpretacji danych sejsmicznych (in Polish). In: Opracowanie map zasięgu, biostratygrafia dolnego paleozoiku oraz analiza ewolucji tektonicznej przykrawędziowej strefy platformy wschodnioeuropejskiej dla oceny rozmieszczenia niekonwencjonalnych złóż węglowodorów (eds. W. Golonka and S. Bębenek): 337-355 Wydawnictwo Arka, Cieszyn.

Kufrasa, M., Stypa, A., Krzywiec, P., Słonka, Ł., 2019. Late Carboniferous thin-skinned deformation in the Lublin Basin, SE Poland: results of combined seismic data interpretation, structural restoration and subsidence analysis. Annales Societatis Geologorum Poloniae, 894.

Kusznir, N.J., Kovkhuto, A., Stephenson, R.A., 1996. Syn-rift evolution of the Pripyat Trough: constraints from structural and stratigraphic modelling. Tectonophysics, 268: 221-236.

Lamarche, J., Lewandowski, M., Mansy, J-L., Szulczewski, M., 2003. Partitioning pre-, syn- and post-Variscan deformation in the Holy Cross Mountains, eastern Variscan foreland. Geological Society Special Publications, 208: 159-184.

Malec, J., 2014. The Devonian/Carboniferous boundary in the Holy Cross Mountains (Poland). Geological Quarterly, 58 (2): 217-234.

Malinowski, M. 2016. Deep reflection seismic imaging in SE Poland using extended correlation method applied to PolandSPAN $^{\mathrm{TM}}$ data. Tectonophysics, 689: 107-114.

Matyja, H., 2006. Stratigraphy and facies development of Devonian and Carboniferous deposits in the Pomeranian Basin and in the western part of the Baltic Basin and palaeogeography of the northern TESZ during Late Palaeozoic times (in Polish with English summary). Prace Państwowego Instytutu Geologicznego, 186: 79-122.

Matyja, H., Stempień-Sałek, 1994. Devonian/Carboniferous boundary and the associated phenomena in Western Pomerania (NW Poland). Annales de la Société géologique de Belgique, 116: 249-263.

Matyja, H., Sobień, K., Marynowski, L., Stempień-Sałek, M., Małkowski, K., 2015. The expression of the Hangenberg Event (latest Devonian) in a relatively shallow-marine succession (Pomeranian Basin, Poland): the results of a multi-proxy investigation. Geological Magazine, 152: 400-428.

Mazur, S., Aleksandrowski, P., Kryza, R., Oberc-Dziedzic, T., 2006. The Variscan Orogen in Poland. Geological Quarterly, 50 (1): 89-118.

Mazur, S., Aleksandrowski, P., Szczepański, J., 2010a. Outline structure and tectonic evolution of the Variscan Sudetes (in Polish with English summary). Przegląd Geologiczny, 58: 133-145.

Mazur, S., Aleksandrowski, P., Turniak, K., Krzemiński, L., Mastalerz, K., Górecka-Nowak, A., Kurowski, L., Krzywiec P., Żelaźniewicz, A., Fanning, M.C., 2010b. Uplift and late orogenic deformation of the Central European Variscan belt as revealed by sediment provenance and structural record in the Carboniferous foreland basin of western Poland. International Journal of Earth Sciences, 99: 47-64.

Mazur, S., Mikołajczak, M., Krzywiec, P., Malinowski, M., Buffenmyer, V., Lewandowski, M., 2015. Is the Teisseyre-Tornquist Zone an ancient plate boundary of Baltica? Tectonics, 34: 465-2477.

Mazur, S., Gągała, Ł., Kufrasa, M., Krzywiec, P., 2018. Application of two-dimensional gravity models as input parameters to balanced cross-sections across the margin of the East European Craton in SE Poland. Journal of Structural Geology, 116: 223-233.

McCann, T., Sliaupa, S., Poprawa, P., Narkiewicz, M., Matyja, H., Lipiec, M., Lazauskiene, J., 1997. The Devonian-Carboniferous tectonic evolution of selected intracratonic and passive margin basins from Central and Eastern Europe: constraints from subsidence analysis, Terra Nostra, 97/11: EUROPROBE TESZ-Meeting, Potsdam, Germany: 85-89. 
McCann,T., Skompski, S., Poty, E., Dusar, M., Vozárová, A., Schneider, J., Wetzel, A., Krainer, K., Kornpihl, K., Schäfer, A., Krings, M., 2008. Carboniferous. In: The Geology of Central Europe (ed. T. McCann), 1: Precambrian and Palaeozoic: 411-529. Geological Society, London.

Migaszewski, Z.M., 2002. K-Ar and Ar-Ar dating of diabases and lamprophyres from the Holy Cross Mts (central Poland) (in Polish with English summary). Przegląd Geologiczny, 50: 227-229.

Mikulski, S. Z., Williams, I. S., Markowiak, M. 2019. Carboniferous-Permian magmatism and Mo-Cu (W) mineralization in the contact zone between the Małopolska and Upper Silesia Blocks (south Poland): an echo of the Baltica-Gondwana collision. International Journal of Earth Sciences, 108: 1467-1492.

Miłaczewski, L., 1981. The Devonian of the south-eastern part of the Radom-Lublin area (eastern Poland) (in Polish with English summary). Prace Instytutu Geologicznego, 101: 1-90.

Mizerski, W., 1995. Geotectonic evolution of the Holy Cross Mts. in Central Europe. Biuletyn Państwowego Instytutu Geologicznego, 372: 1-49.

Moryc, W., 2006. The geological structure of the Miocene substratum in the Kraków-Pilzno region. Part 1. Precambrian and $\mathrm{Pa}$ leozoic (without Permian) (in Polish with English summary). Nafta-Gaz, 72: 197-216.

Narkiewicz, K., Narkiewicz, M., 2008. The mid-Frasnian subsidence pulse in the Lublin Basin (SE Poland): sedimentary record, conodont biostratigraphy and regional significance. Acta Geologica Polonica, 58: 287-301.

Narkiewicz, M., 1988. Turning points in sedimentary development in the Late Devonian in southern Poland. Canadian Society of Petroleum Geologists, Memoir, 14: 619-635.

Narkiewicz, M., 2003. Tectonic controls of the Lublin Graben (Late Devonian-Carboniferous) (in Polish with English summary). Przegląd Geologiczny, 51: 771-776.

Narkiewicz, M., 2005. Devonian and Carboniferous carbonate complex in the southern part of the Upper Silesian Block (in Polish with English summary). Prace Państwowego Instytutu Geologicznego, 182: 1-46.

Narkiewicz, M., 2007. Development and inversion of Devonian and Carboniferous basins in the eastern part of the Variscan foreland (Poland). Geological Quarterly, 51 (3): 231-256.

Narkiewicz, M., 2011a. Lithostratigraphy, depositional systems and transgressive-regressive cycles in the Middle Devonian to Frasnian of the Łysogóry-Radom Basin (south-eastern Poland) (in Polish with English summary). Prace Państwowego Instytutu Geologicznego, 196: 7-52.

Narkiewicz, M., 2011b. Lithostratigraphy, depositional systems and transgressive-regressive cycles in the Devonian of the Lublin Basin (south-eastern Poland) (in Polish with English summary). Prace Państwowego Instytutu Geologicznego, 196: 53-146.

Narkiewicz, M., 2019. Comment on "Depth-to-basement for the East European Craton and Teisseyre-Tornquist Zone in Poland based on potential field data" by Mikołajczak et al. International Journal of Earth Sciences. 108: 1763-1765.

Narkiewicz, M., Petecki, Z., 2016. Comment on "Is the Teisseyre-Tornquist Zone an ancient plate boundary of Baltica?" by Mazur et al. Tectonics, 35: 1595-1599.

Narkiewicz, M., Petecki, Z., 2017. Basement structure of the Paleozoic Platform in Poland. Geological Quarterly, 61 (2): 502-520.

Narkiewicz, M., Petecki, Z., 2019. Teisseyre-Tornquist Zone evolving approaches and new data (in Polish with English summary). Przegląd Geologiczny, 67: 837-848.

Narkiewicz, M., Poprawa, P., Lipiec, M., Matyja, H., Miłaczewski, L., 1998. Paleogeographic and tectonic setting and the Devonian-Carboniferous subsidence development of the Pomerania and Radom-Lublin areas (TESZ, Poland) (in Polish with English summary). Prace Państwowego Instytutu Geologicznego, 165 31-46.

Narkiewicz, M., Jarosiński, M., Krzywiec, P., 2007. Diagenetic and tectonic processes controlling reservoir properties of the Frasnian dolostones in the central part of the Lublin Graben (Eastern Poland) (in Polish with English summary). Przegląd Geologiczny: 55: 61-70.
Narkiewicz, M., Narkiewicz, K., Turnau, E., 2011a. Devonian depositional development of the Łysogóry-Radom and Lublin Basins (south-eastern Poland) (in Polish with English summary). Prace Państwowego Instytutu Geologicznego, 196: 289-318.

Narkiewicz, M., Grad, M., Guterch, A., Janik, T., 2011b. Crustal seismic velocity structure of southern Poland: preserved memory of a pre-Devonian terrane accretion at the East European Platform margin. Geological Magazine, 148: 191-210.

Narkiewicz M., Maksym A., Malinowski M., Grad M., Guterch A., Petecki Z., Probulski J., Janik T., Majdański M., Środa P., Czuba W., Gaczyński E., Jankowski L., 2015. Transcurrent nature of the Teisseyre-Tornquist Zone in Central Europe: results of the POLCRUST-01 deep reflection seismic profile. International Journal of Earth Sciences, 104: 775-796.

Nawrocki, J., Becker, A., eds., 2017. Atlas geologiczny Polski (in Polish). Państwowy Instytut Geologiczny - Państwowy Instytut Badawczy, Warszawa.

Nawrocki, J., Salwa, S., Pańczyk, M., 2013. New ${ }^{40} \mathrm{Ar}-{ }^{39} \mathrm{Ar}$ age constrains for magmatic and hydrothermal activity in the Holy Cross Mts. (southern Poland). Geological Quarterly, 57 (3): 551- 560 .

Nikishin, A.M., Ziegler, P.A., Stephenson, R.A., Cloetingh, S.A.P.L., Furne, A.V., Fokin, P.A., Arshov, A.V., Bolotov, S.N., Korotaev, M.V., Alekseev, A.S., Gorbachev, V.I., Shipilov, E.V., Lankreijer, A., Bembinova, E.Yu., Shalimov, I.V., 1996. Late Precambrian to Triassic history of the East European Craton: dynamics of sediimentary basin evolution. Tectonophysics, 268: 23-63.

Okay, A.I., Topuz, G., 2017. Variscan orogeny in the Black Sea region. International Journal of Earth Sciences, 106: 569-592.

Oncken, O., Von Winterfeld, C., Dittmar, U., 1999. Accretion of a rifted passive margin: the Late Paleozoic Rhenohercynian fold and thrust belt (Middle European Variscides). Tectonics, 18: 75-91.

Opluštil, S., Schmitz, M., Kachlík, V., Štamberg, S. 2016. Re-assessment of lithostratigraphy, biostratigraphy, and volcanic activity of the Late Paleozoic Intra-Sudetic, Krkonoše-Piedmont and Mnichovo Hradiště basins (Czech Republic) based on new U-Pb CA-ID-TIMS ages. Bulletin of Geosciences, 91: 399-432.

Pańczyk, M., Nawrocki, J., 2015. Tournaisian ${ }^{40} \mathrm{Ar} /{ }^{39} \mathrm{Ar}$ age for alkaline basalts from the Lublin Basin (SE Poland). Geological Quarterly, 59 (3): 473-478.

Papiernik, B., Lapinkiewicz, A.P., Górecki, W., 2007. Petrophysical conditions of oil and gas productivity of Devonian and Carboniferous deposits in the southern part of the Miechów Trough in the light of computer modelling results (in Polish with English abstract). Geologia, 33: 341-374.

Pożaryski, W., Dembowski Z., eds., 1983. Geological map of Poland and neighbouring countries without Cenozoic, Mesozoic and Permian deposits, 1:1 000 000. Instytut Geologiczny, Warszawa.

Pożaryski, W., Karnkowski, P., eds., 1992. Tectonic map of Poland during the Variscan time. Wyd. Geol., Warszawa.

Pożaryski, W., Grocholski, A., Tomczyk, H., Karnkowski, P., Moryc, W., 1992. The tectonic map of Poland in the Variscan epoch (in Polish with English summary). Przegląd Geologiczny, 40: 643-651.

Racki, G., Narkiewicz, M., 2000. Tectonic versus eustatic controls of sedimentary development of the Devonian in the Holy Cross Mts., Central Poland (in Polish with English summary). Przegląd Geologiczny, 48: 65-76.

Racki, G., Zapaśnik, T., 1979. Some remarks on the tectonics of Devonian rocks in the Gałęzice syncline (in Polish with English summary). Przegląd Geologiczny, 27: 154-158.

Ricken, W., Schrader, S., Oncken, O., Plesch, A., 2000. Turbidite basin and mass dynamics related to orogenic wedge growth: the Rhenohercynian case. Geological Society Special Publications, 179: $257-280$.

Sandberg, C.A., Morrow, J.R., Ziegler, W., 2002. Late Devonian sea-level changes, catastrophic events, and mass extinctions. GSA Special Paper, 356: 473-487. 
Schulmann, K. Gayer, R., 2000. A model for a continenta accretionary wedge developed by oblique collision the NE Bohemian Massif. Journal of the Geological Society, 157: 401-416.

Stephenson, R.A., Yegorova, T., Brunet, M.F., Stovba, S., Wilson, M., Starostenko, V., Saintot, A.,Kusznir, N., 2006. Late Palaeozoic intra-and pericratonic basins on the East European Craton and its margins. Geological Society Memoirs, 32: 463-479.

Szaniawski, R., 2008. Late Paleozoic geodynamics of the Małopolska Massif in the light of new paleomagnetic data for the southern Holy Cross Mountains. Acta Geologica Polonica, 58: $1-12$.

Szulczewski, M., 1995. Depositional evolution of the Holy Cross Mts. (Poland) in the Devonian and Carboniferous - a review. Geological Quarterly, 39 (4): 471-488.

Tomaszczyk, M., 2016. Ewolucja tektoniczna centralnej części basenu lubelskiego (in Polish). Ph.D. thesis, Polish Geological Institute-NRI, Warszawa.

Tomaszczyk, M., Jarosiński, M., 2017. The Kock Fault Zone as an indicator of tectonic stress regime changes at the margin of the East European Craton (Poland). Geological Quarterly, 61 (4): 908-925.

Waksmundzka, M.I., 2010. Sequence stratigraphy of Carboniferous paralic deposits in the Lublin Basin (SE Poland). Acta Geologica Polonica, 60: 557-597.

Ziegler, P.A., 1990. Geological Atlas of Western and Central Europe, 2nd edn. Shell Internationale Petroleum Maatschappij BV Den Haag.
Znosko, J., 1992. Outline of post-Variscan geotectonic evolution of Poland. Bulletin Polish Academy of Sciences, Earth Sciences, 40: 315-320.

Żaba, J., 1999. The structural evolution of Lower Palaeozoic succession in the Upper Silesia Block and Małopolska Block border zone (southern Poland) (in Polish with English summary). Prace Państwowego Instytutu Geologicznego, 166: 1-162.

Żaba, J., Poprawa, P., 2006. Deformation history of the Koszalin-Chojnice zone (Pomeranian segment of TESZ, NW Poland) constrahints from structural analysis of Palaeozoic and Mesozoic successions in Polskie Łąki PIG 1 and Toruń 1 boreholes (in Polish with English summary). Prace Państwowego Instytutu Geologicznego, 186: 225-252.

Żakowa, H., Migaszewski, Z., 1995. Holly Cross Mts. (in Polish with English summary). Prace Państwowego Instytutu Geologicznego, 148: 109-115.

Żelaźniewicz, A., Pańczyk, M., Nawrocki, J., Fanning, M., 2008. A Carboniferous/Permian, calc-alkaline, I-type granodiorite from the Małopolska Block, Southern Poland: implications from geochemical and U-Pb zircon age data. Geological Quarterly, 52 (4): 301-308.

Żelichowski, A.M., 1987. Development of the Carboniferous of the SW margin of the East-European Platform in Poland (in Polish with English summary). Przegląd Geologiczny, 35: 230-237.

Żelichowski, M., Kozłowski, S., eds., 1983. Atlas of geological structure and mineral deposits in the Lublin Region (in Polish with English summary). Instytut Geologiczny, Warszawa. 